\title{
Barriers to university-industry collaboration in an emerging market: Firm-level evidence from Turkey
}

\author{
Timo Kleiner-Schaefer ${ }^{1,2}$ (D) $\cdot$ Kerstin J. Schaefer ${ }^{3}$ iD
}

Accepted: 5 January 2022 / Published online: 4 February 2022

(c) The Author(s) 2022

\begin{abstract}
University-industry collaborations (UICs) are one of the main sources of external knowledge and technologies for industrial firms, particularly in the context of emerging markets (EMs) and firm development. It is thus highly relevant to identify potential barriers internal to the firm as well as in the regional innovation system that might prevent firms from using UICs for innovation, in particular in an EM context. In order to address this issue, we conduct a firm-level study of the R\&D-related segment of the manufacturing industry in Istanbul. Logistic regression analysis is used to test the effect of potential barriers on using UICs for innovative activities. With this approach, we are able to identify barriers that prevent innovation-related UICs and thus form a bottleneck to collaborations in the first place. Our findings show that lack of information about UIC opportunities as well as lack of financial support for UICs are the most relevant barriers that inhibit firms' usage of UICs for innovation. This firm-level evidence points out the importance of university technology transfer offices in regional innovation systems and for fruitful UICs. We further find that administrative barriers have no significant effect, while barriers related to trust and skill matching with scientific partners even have a reverse effect to what we would have expected from the literature. This finding might point towards an effect of perceived versus deterring barriers that has been observed in innovation studies before and might be relevant for studying UICs as well.
\end{abstract}

Keywords Innovation · Research and development - University-industry collaboration · Barrier · Emerging market · Turkey

JEL Classification $\mathrm{O} 30 \cdot \mathrm{O} 32 \cdot \mathrm{O} 38$

Timo Kleiner-Schaefer

kleiner@wigeo.uni-hannover.de

Kerstin J. Schaefer

schaefer@wigeo.uni-hannover.de

1 Institute of Economic and Cultural Geography, Leibniz Universität Hannover, Schneiderberg 50, 30167 Hannover, Germany

2 Department for Structural Development, Research and Transfer, Philipps-Universität Marburg, Biegenstraße 10, 35032 Marburg, Germany

3 Department of Geography and Environment, London School of Economics and Political Science, Houghton Street, London WC2A 2AE, UK 


\section{Introduction}

University-industry collaborations (UICs) are one of the most important interactions for transferring knowledge or technologies, stimulating growth and improving innovative activities. However, setting up collaborations between universities and industrial firms can be difficult to achieve. In fact, there are often differences between these institutions in terms of expectations, requirements and collaboration goals (Bjerregaard, 2010; Gilsing et al., 2011; Muscio \& Pozzali, 2013). Additional barriers are the costs for firms to search partners that are willing to collaborate and that have a fitting level of skills as well as the costs that are related to the collaboration itself (Bruneel et al., 2010; D'Este et al., 2014; Garcia et al., 2019; Temel \& Glassman, 2013). It is thus important to address potential barriers to UICs which is of particular concern in emerging markets (EMs) as UICs are discussed as an important external knowledge source to improve the innovative performance of firms in such contexts (Bastos et al., 2014; Guerrero et al., 2019; Mathews \& Hu, 2007). In this article, we thus study the barriers to innovation-related UICs for the case of Turkey and Istanbul in particular.

The present body of literature about UICs covers various topics such as forms of collaboration or transfer channels, enabling factors for successful collaboration as well as barriers to its success. Most studies, however, stem from an industrialized country context and if not focus on EM firms' insights, primarily from China, India or Latin America, leaving other EM contexts under-researched (Jormanainen \& Koveshnikov, 2012). As a result, the question arises as to how well theories and implicit assumptions from a Western context apply to EMs and whether there are chances to gain new insights for the generalizability of existing theories (Beyhan \& Cetindamar, 2011; Collings et al., 2010; Liefner, 2013; Ramamurti \& Singh, 2009). It is thus highly relevant to extend existing knowledge towards explorative studies from EMs to understand different experiences on the basis of varying institutional contexts and diverse economic structures (Cetindamar et al., 2009; Kruss \& Visser, 2017) and thus be able to inform policy in respective economies (Filippetti \& Savona, 2017). This is even more important considering the fact that EMs will play a major role in the future globalized economy, meaning that we need to learn more about these diverse settings and further develop the field of EM research (Nielsen et al., 2018) as well as expanding or enriching existing theories in new ways (Ramamurti, 2016). This is particularly true for the seven largest EMs according to their gross domestic product (GDP), namely Brazil, Russia, India, China, Mexico, Turkey and Indonesia (Guégan et al., 2014). For the Turkish case, barriers to UICs are also still under-researched with only few studies concerning this topic. For this reason, we extend the empirical scope on the barriers to UICs for the EM of Turkey.

In order to understand the emergence of innovations through regional collaborations, the regional contexts or settings play a major role for research and development (R\&D) activities of firms and for the emergence and success of UICs. In this regard, regional innovation systems (RISs) denote a concept that involve institutions from industry, academia and politics as well as their interactions with each other (Cooke et al., 1997, 1998; Etzkowitz \& Leydesdorff, 2000). Lee (2019) points out that it is vital for EMs to build their own innovation systems in which domestic firms can grow their capabilities instead of imitating practices used in established economies that might not be suitable.

In our case study of the Turkish context, we observe industrial firms' collaboration activities with universities based in Istanbul and the Marmara region. By using an original survey sample of the R\&D-related segment of manufacturing firms, we answer our 
research question about obstacles to UICs during the innovation process: 'What barriers prevent firms' use of UICs for achieving innovation?'. Hereof, we use a logistic regression analysis to test several obstacles to UICs for two groups of firms that either do or do not use collaboration with universities as an external knowledge source during their innovation process. By doing so, we are able to identify barriers that actually prevent UICs and thus form a bottleneck to collaborations. Our findings reveal a lack of knowledge about UIC opportunities as well as insufficient external financial support as the two most relevant barriers to successful collaborations, which are in contrast to previous findings from the context of Turkey and other EMs. Moreover, it becomes apparent that trust issues and skill mismatches are perceived more strongly as barriers from the perspective of firms that actually do use UICs for innovative activities. We thus contribute to the literature that in EM contexts, external support for UICs is crucial, in terms of providing information about collaboration opportunities as well as direct financial support, enabling firms to collaborate with scientific partners. Moreover, our results show that we might need to differentiate between barriers preventing UICs and barriers affecting existing collaborations.

This paper is organized as follows. Firstly, the theoretical frameworks about the setting for innovations and barriers to UICs in EMs are presented. In doing so, hypotheses are developed based on the literature review of underlying theories and existing studies, primarily from EM contexts. Secondly, we provide insights about the contextual setting for innovation and UICs in Istanbul. Thirdly, our survey sampling, data collection, measurement of the variables and subsequent empirical data analysis are outlined. Following this, logistic regression analysis is used to test the impact of barriers to UICs in view of firms' innovation strategies. Finally, results are discussed, limitations are outlined and economic, managerial and policy implications are drawn.

\section{Theoretical frameworks and hypotheses development}

\subsection{The role of UICs in EMs}

Lee (2019) identifies the failure to build innovation capability as one of the main failures that keep EM firms from catching up on established economies. This is particularly important for firms in EMs in relation to an increase in competition from foreign direct investments (FDIs) and the need for upgrading their technology (Figueiredo \& Piana, 2021; Kotabe et al., 2011; Pavitt, 1990; Prahalad \& Hamel, 1990).

Chari (2015) developed an integrated model for the main literature strands on EM firms' catch-up and upgrading process, namely upgrading through spillovers, linkages, acquisitions and internal R\&D. One of the main mechanisms for building innovative capabilities are spillovers from FDIs or international R\&D alliances (Blomström \& Kokko, 1998; Görg \& Greenaway, 2004; Kim \& Inkpen, 2005; Zhang et al., 2010). However, prior to accessing knowledge sources that are external to the firm, it is necessary that companies achieve and obtain sufficient levels of internal knowledge or R\&D capacities (Barney, 1991; Eisenhardt \& Martin, 2000; Teece et al., 1997) to successfully identify, adopt and use innovation or technologies (Abreu, 2011; Chesbrough, 2003; W. M. Cohen \& Levinthal, 1989, 1990; Lin et al., 2002). In this regard, FDIs or the import of technology can facilitate the building of technological capabilities of EM firms only if absorptive capacities are prevalent (Kumar et al., 1999). Together with a strategic positioning in network structures, firms need these absorptive capabilities in order to enhance their performance and innovativeness (Stojčić, 
2021; Tsai, 2001; Zaheer \& Bell, 2005). A similar argument is raised by Lee (2019), who points out that many firms in EMs are unable to conduct in-house $R \& D$, as they need to cultivate basic R\&D capabilities in the first place. He therefore suggests that a more effective form of learning might be transferring R\&D outcomes from public research institutes for building basic capabilities in the first place. Other studies have shown that knowledge sourcing from universities plays a major role for manufacturing firms as it evidently influences firms' innovativeness (Lööf \& Broström, 2008). Moreover, a study by Findık and Beyhan (2015) shows the impact of UICs on the innovation performance of Turkish firms and find a strong positive relationship between firms' product and process improvements and their collaborations with external partners. UICs thus provide firms in EMs with the opportunity to increase their internal $R \& D$ capabilities as well as their innovativeness consequently.

For becoming more competitive, UICs in terms of knowledge and technology transfer are thus considered the most important external knowledge source for firms (Kaufmann \& Tödtling, 2001; Mascarenhas et al., 2018), particularly in EMs (Bastos et al., 2014; Guerrero et al., 2019; Mathews \& Hu, 2007) and with universities that are spatially close by, as geographic proximity facilitates all forms of UICs and is positively associated with the frequency and quality of collaborations (Broström, 2010; Crescenzi et al., 2017; D’Este \& Iammarino, 2010; D'Este et al., 2013; De Fuentes \& Dutrénit, 2016; Laursen et al., 2011; Tang et al., 2020). The importance of close proximity between actors in a RIS is summarized in the triple helix model, which was originally developed within advanced market contexts. This concept captures the activities and interactions between the political sphere, academia and firms on an institutional level, and thus provides an ideal systematic approach for observing the emergence and development of knowledge within a regional environment (Etzkowitz \& Leydesdorff, 2000). In industrialized country contexts, RISs are major success factors for thriving regional economic growth. Governmental institutions thus try to implement measures to strategically support firms in their innovative efforts and encourage the emergence of UICs. Further developments and adaptions of the model also allow the realization of its usage within a developing or EM setting, where it has previously been a normative rather than an analytic concept (Etzkowitz et al., 2005). On that account, an increasing number of EMs are establishing similar systems to foster innovation and regional economic development consequently (Albuquerque et al., 2015). Other scholars, however, criticize the triple helix concept as not providing a realistic guiding framework to discuss UICs in developing countries (Eun et al., 2006).

Nevertheless, within a RIS or triple helix concept, in addition to specific demands and requirements from the firm side or governance claims of regional policymakers, universities play a particular role and need to adapt prior to an interaction with industrial firms. The provision of a university-trained workforce through their tertiary education function is thus only a basic requirement for firms' upgrading (Lall, 2000), with a much greater need for the development of universities from having a sole focus on teaching and basic research to a more widened perspective or emerging 'third role' in terms of entrepreneurial engagement and application or commercialization of scientific knowledge (Etzkowitz et al., 2000). Ultimately, applied knowledge becomes the relevant factor for interacting with partners outside the scientific environment and fosters firms' capability development in particular in EMs. Different features or cultures of universities and firms, however, can constitute a principal barrier to UICs. Overall, it is thus important to note that universities are not simple repositories of exploitable knowledge that are easily available to firms. In contrast, existing obstacles to communication and technology transfer in UICs need appropriate mechanisms to remove respective barriers and facilitate bi-directional interactions (Uyarra, 2010). 
It is also relevant to consider that universities in EMs might not be able to contribute to upgrading at the firm or regional level immediately, but need time to transform their organizational and functional structures in the first place to develop academic capacities or evolve into an entrepreneurial university. For the case of Central and Eastern Europe, Stojčić (2021) reveals the only very limited extent of UICs with at best incremental innovations or imitations as outcome of such collaborations (Stojčić, 2021). In a study by Schiller and Lee (2015) from five emerging Asian countries, the authors show that UICs do not have a statistically significant impact on the catch-up process of the respective EMs. These findings are based on low academic and technological capabilities at the university as well as the firm level, and consequently lead to only minor UICs. Instead, domestic firms rely on foreign knowledge sources or collaboration with customers and parent companies (Schiller \& Lee, 2015). Ranga et al. (2016) analyze the technology transfer capacities of Turkish universities critically and emphasize their still nascent stage of UIC experiences. This finding is mainly based on weak technological foci and a lack of market or commercialization orientation that lead to several obstacles in terms of licensing, patenting and spin-offs (Ranga et al., 2016). Moreover, Temel et al. (2013) explored the effects of firms' collaboration with external partners and their innovativeness and find that UICs do not enhance firms' innovation success. The authors explain this finding with a rather strong teaching focus of Turkish universities, low absorptive capacities of Turkish firms and only a few efficient technology transfer offices (TTOs) available (Temel et al., 2013). It is thus unclear to what extent universities in EMs are even able to generate new knowledge or commercialize their research, promote a technological upgrading process and thus function as a driver of a high-technological development (Chatterjee \& Sankaran, 2015; Doutriaux, 2003), as they might merely contribute in their educative function to build up human capital within learning systems (Schiller \& Liefner, 2007).

\subsection{Barriers to UICs and hypotheses development}

In the next section, we shed some light on the literature about UIC barriers with an emphasis on EMs overall and Turkey in particular. The literature has investigated how UICs can work successfully through insights from firms' activities in industrialized or newly emerged economy contexts. Many review articles by Agrawal (2001), D'Este and Patel (2007), Bekkers and Bodas-Freitas (2008), Mascarenhas et al. (2018), Skute et al. (2019) as well as Rybnicek and Königsgruber (2019) provide systematic overviews of the state of UIC literature and identify theoretical key aspects of transfer or interaction channels and promoting factors of UICs.

In regard to UIC barriers from the perspective of industrial firms and academics, Ankrah and AL-Tabbaa (2015) outline factors that either facilitate or impede UICs and sort these into categories of capacities and resources, legal and contractual mechanisms, managerial and organizational issues, technology-related issues, political and social issues as well as other potential obstacles. De Wit-de Vries et al. (2019) identify influencing factors of knowledge transfer in academic engagement that are related to cognitive and institutional differences, varieties of goals and social capital. Nsanzumuhire and Groot (2020) categorize existing studies about UIC obstacles into misalignment, motivation, capability, governance, and context-related barriers, and furthermore distinguish between factors from developed and developing countries. In terms of inhibiting factors for UICs, it is also relevant how many UIC barriers firms perceive. Antonioli et al. (2017) show that firms which only face single constraints use cooperation as a coping strategy to deal with the respective 
barriers, whereas the presence of multiple and varying barriers inhibits the establishing of UICs, particularly if firms lack financial resources, skills or knowledge about markets and technologies (Antonioli et al., 2017). We follow these previous studies by summarizing four distinct categories of barriers: R\&D capability, lack of external support structures, mismatch with collaboration partners and administrative barriers. In the subsequent sections, we present the development of our hypotheses based on this literature.

\subsubsection{R\&D capabilities' impact on UIC barriers}

Internal knowledge sources and absorptive capacities are the two main determinants for incorporating incoming spillovers and increasing the likelihood and intensity of R\&Drelated UICs (Aristei et al., 2016; Beyhan \& Find1k, 2014). D’Este et al. (2014) highlight the relevance of R\&D-related personnel at firm level. Therefore, high levels of human capital or internal R\&D capabilities have a positive impact on reducing firms' barriers to achieve innovations and can thus facilitate successful knowledge transfers with universities. Kanama and Nishikawa (2017) likewise mention the importance of internal knowledge or human resources with specific skills. The authors emphasize that firms engage less frequently in UICs when they face a shortage of R\&D-related personnel that is capable of conducting search activities for appropriate collaboration partners or technology transfer (Kanama \& Nishikawa, 2017). In addition, not only internal skills or capabilities, but also external resources are highly important for firms' innovation and upgrading strategies (Chesbrough, 2010; Cohen \& Levinthal, 1989, 1990; Teece et al., 1997). This becomes even more relevant if firms lack internal R\&D resources or have no knowledge about the regional economic environment. Technology transfers via UICs as an external knowledge source might therefore gain center stage in firms' successful innovation processes. Other studies also clearly show that the intensity of internal R\&D positively and significantly stimulates R\&D activities with external partners such as universities (Becker \& Dietz, 2004; Bercovitz \& Feldman, 2007).

In a study on the innovation success of R\&D-oriented companies in Turkey, KleinerSchäfer and Liefner (2021) show that for domestic Turkish firms, internal R\&D resources are the main success factor for achieving innovations, whereas external R\&D resources have no influence. Respective firms thus still need to build their internal capabilities prior to assessing and using external knowledge and technology sources for their innovation activities. This is particularly true for technological knowledge sources that are related to collaboration and learning from scientific partners (Kleiner-Schäfer and Liefner, 2021). Furthermore, De Fuentes et al. (2020) explored perceived barriers to innovation on the part of successful and unsuccessful innovating firms for the EM settings of Turkey and Mexico. The authors identify diverse firm and context specific characteristics that influence firms' perception of barriers and that differ between successful and unsuccessful innovators. Their findings relate to financial, organizational, labor, regulatory as well as public support barriers. As a result, De Fuentes et al. (2020) show that for large unsuccessful firms, barriers related to qualified labor and a lack of public support are most relevant, whereas small firms perceive regulatory barriers as most hindering. Overall and highly important, low numbers of R\&D personnel are a commonly perceived barrier to innovation (De Fuentes et al., 2020). Firms' internal R\&D capabilities thus constitutes a highly relevant factor for diminishing innovation obstacles at firm level. Our study builds upon these findings, but we further extent the understanding of firms' innovation success with more detailed information about firms' external knowledge sourcing in terms of UICs and particularly barriers 
to such. By doing so, we emphasize on the importance of UICs for the innovation success of firms in EMs.

Based on the importance of firms' internal knowledge, abilities or capabilities for UICs, we assume that higher R\&D capabilities lower the barrier of using UICs for achieving innovation. We thus hypothesize:

H.1 Higher 'R\&D capabilities' decrease the barrier to using UICs for innovation. ( $R \& D$ capabilities)

\subsubsection{External support barriers}

D'Este et al. (2014) show that financial obstacles in terms of missing external funding for innovation are a highly relevant barrier for firms that already engage in innovation (D'Este et al., 2014). Therefore, public financial support is an important factor to lower the barriers for firms to engage in innovation. Public R\&D funding and particularly firm size positively influence a firm's R\&D proportion in external partnerships with universities and increase the chances for further or more intense UICs and R\&D collaborations (Aristei et al., 2016; De Fuentes \& Dutrénit, 2016; Fontana et al., 2006; Laursen \& Salter, 2004; Segarra-Blasco \& Arauzo-Carod, 2008; Yu \& Lee, 2017). If internal R\&D capabilities are scarce or missing, based on relatively smaller firm size, political or public financial support is thus all the more important.

In a study from Mexico, Guerrero et al. (2019) show that firms predominately use UICs to explore new knowledge, to gain access to resources and capabilities from universities, to engage in long-term and radical innovation activities as well as to access public funds and subsidies that are tied to mandatory UIC activities (Guerrero et al., 2019). In addition, Guerrero and Urbano (2017) also highlight positive effects of financial support for innovation that are only evident if firms successfully collaborate with universities (Guerrero \& Urbano, 2017). D'Este and Perkmann (2011) suggest, however, that instead of solely or excessively focusing on financial incentives for industrial engagement in UICs, a more comprehensive policy strategy should be pursued for promoting collaboration, referring to the needs and requirements of scientific personnel rather than expecting a merely entrepreneurial mindset of universities and their academic researchers (D'Este \& Perkmann, 2011).

Within the Turkish context, Beyhan and Rickne (2015) point out the relevance of industry funding and academics' motivations towards knowledge commercialization during UICs (Beyhan \& Rickne, 2015). Temel and Glassman (2013) also emphasize the importance or necessity of funds for UICs for the case of Turkish firms and universities (Temel \& Glassman, 2013). In a study on collaboration activities of Turkish manufacturing firms, however, Cetindamar and Ulusoy (2008) find that firms only collaborate with other firms to a high degree, although the impact on their innovation performances is very limited. In fact, collaboration with universities or scientific partners could even be neglected in terms of its impact on firms' innovativeness (Cetindamar \& Ulusoy, 2008). Şendoğdu and Diken (2013) also find a positive correlation between the frequency of UICs and upcoming problems among Turkish firms in Konya (Şendoğdu \& Diken, 2013). It thus becomes evident, that external support from governmental institutions play an important role to foster UICs with different means. In this regard, Yüksel and Cevher (2014) conducted a study about UIC processes in Turkey and identified the relevant institutions or measures that foster collaboration activities. The authors describe UICs as an emerging concept within Turkey with potential for improvement and identify several governmental programs 
and institutions that constitute relevant support infrastructure for UICs (Yüksel \& Cevher, 2014). Nevertheless, Yalçıntaş et al. (2015) observe different forms of UICs as not known well enough among scientific personnel, meaning that insufficient information as well as the setup and management of $R \& D$ projects are perceived as highly negative aspects. In this, TTOs are described as the most advantageous and effective support structure for UICs (Yalçıntaş et al., 2015). Moreover, Ciritcioglu et al. (2016) identify key obstacles to UICs among firms in the woodworking industry in the East Marmara region. According to the authors, most firms have insufficient knowledge about collaboration opportunities or have little interest therein. In addition, miscommunication between firms and universities seems to be the main reason for weak UICs, meaning that TTOs or technology support facilities can be helpful to strengthen collaborations (Ciritcioğlu et al., 2016).

In terms of the importance of knowledge about UICs as well as the relevance of financial and political support to establish such, we assume that a lack of respective factors might inhibit firms' use of UICs for achieving innovation. We consequently hypothesize that:

H.2 'Lack of information about UIC opportunities' increases the barrier to using UICs for innovation. (Information barrier)

H.3 'Lack of financial support for UICs' increases the barrier to using UICs for innovation. (Financial support barrier)

\subsubsection{Collaboration partner barriers}

Bjursell and Engström (2019) find several hindering factors that influence UICs on the individual as well as on the intra- and inter-organizational level. The authors highlight the importance of removing collaboration obstacles rather than adding driving forces for UICs. In this regard, establishing trust and openness towards varying collaboration partners' needs or goals as well as implementing rewards systems and resource allocations are the most important measures to diminish UIC barriers (Bjursell \& Engström, 2019). De Wit-de Vries et al. (2019) also emphasize that trust, communication, experience and the use of intermediary institutions are highly relevant facilitators to help resolve UIC barriers (de Wit-de Vries et al., 2019). Furthermore, findings from Bruneel et al. (2010) likewise show that establishing trust between firms and universities is the main mechanism for lowering barriers in UICs. This holds particularly true for diminishing or mitigating orientation and transaction-related barriers, referring to divergent expectations, varying rules and regulations, and protection of intellectual property rights (IPRs) (Bruneel et al., 2010). Giaretta (2014) likewise emphasizes the importance of trust builders in technology transfer relationships between firms and their external knowledge sources. Hereof, the author encourages a problem solution at firm level by implementing a dialogue facilitation model with internal personnel as boundary spanners between institutions (Giaretta, 2014). Moreover, Oliver et al. (2020) also highlight the importance of high levels of trust for successful UICs. The authors identify two levels of trust on both the individual and organizational level. In this regard, scientists' reputation as well as shared values are vital trust factors on the individual level, whereas efficiency and contract specification are relevant trust builders on the organizational level. Overall, complex processes on both levels and a lack of 
collaboration experience often result in huge challenges to build and maintain trust in UICs (Oliver et al., 2020).

Gilsing et al. (2011) focus on the difference of technology transfer mechanisms and barriers between science-based and development-based industries and identify key aspects in both regimes. While the transfer mechanisms are relatively different from each other, the authors find distinct similarities among major barriers to the technology transfer process, such as conflicts of interest, risk of information leakage or too general scientific knowledge (Gilsing et al., 2011). Aycan (2001) likewise mentions an imbalance between science and practice, describing a partly negative attitude of Turkish firms towards using scientific knowledge sources (Aycan, 2001). For the EM of Brazil, Garcia et al. (2019) find transactional barriers in terms of trust and IPR issues as important factor inhibiting more collaboration between academics and industrial partners (Garcia et al., 2019). Furthermore, Lopes and Lussuamo (2021) find low experience levels and a lack of inter-organizational trust between firms and universities as the most frequent UIC barriers for the context of developing regions in EMs (Lopes \& Lussuamo, 2021). Hall et al. (2001) show that IPR issues might act as an unbridgeable barrier between firms and universities, particularly if projects are rather short-term and knowledge or technologies are difficult to commercialize. In contrast, fewest barriers are present if projects are long-term-oriented, technologies are applicable for firms, and lead participants in UICs have prior knowledge therein (Hall et al., 2001). In addition, Temel and Glassman (2013) further highlight firms' perception of less skilled or less knowledgeable scientific personnel than their own employees as a major barrier preventing R\&D collaborations between Turkish firms and universities (Temel \& Glassman, 2013).

In this respect, a lack of trust and perceived inadequately skilled universities in the view of firms can lead to considerable collaboration process barriers, preventing the emergence of successful UICs. We thus hypothesize:

H.4 'Lack of trust in collaboration partners' increases the barrier to using UICs for innovation. (Trust barrier)

H.5 'Perception of inadequately skilled collaboration partners' increases the barrier to using UICs for innovation. (Skill barrier)

\subsubsection{Administrative barriers}

Bruneel et al. (2010) identify more 'classic' barriers related to institutional differences such as time orientation and administrative procedures as still remaining substantial in UICs (Bruneel et al., 2010). Tartari et al. (2012) specify two main sets of barriers to UICs that are related to the orientation of academic research and the transactional costs of collaborating with industrial firms. The authors find differences in timescales between academic researchers and firms as most important barrier to UICs. In this regard, research orientation-related barriers can be reduced by academics' experience with UICs or industrial work. Reducing transactional costs, however, is more complex, as these are often related to conflicts with TTOs, based on the intermediaries' low profiles and lack of flexibility. As a consequence, the operating environment plays a vital role for academics' engagement in UICs (Tartari et al., 2012). Furthermore, Muscio and Vallanti (2014) indicate perceived barriers that relate to a misalignment of commercial benefits or incentives of UICs, 
conflicting collaboration goals as well as too much cognitive distance between academic research and business needs. This holds particularly true if collaboration partners are inexperienced in UICs (Muscio \& Vallanti, 2014). In addition, Ramli and Senin (2015) identify various factors for diminishing orientation and resource-related barriers to UICs, as limited time and lacking resources are key factors that hinder successful collaborations (Ramli \& Senin, 2015). Garcia et al. (2019) also note that perceived transactional factors or costs such as bureaucracies or administrative procedures act as a major barrier or discouragement to more collaboration with industrial firms in the EM of Brazil (Garcia et al., 2019). In an analysis of firms' commercialization of innovation, Stojčić (2021) also shows cognitive proximity between collaboration partners as more important than other proximity factors such as geographical, organizational or social proximity (Stojčić, 2021).

For the EM of Turkey, Aycan (2001) shows that a main aspect of firms' bias towards collaboration with academics is the time intensive factor, which is considered as highly costly for firms. Instead, Turkish organizations mostly worked with consulting firms that based their practices and knowledge on sources other than scientific knowledge (Aycan, 2001). Moreover, Demirbas et al. (2011) examine perceived barriers to innovation activities of Turkish small- and medium-sized enterprises (SMEs) and find institutional barriers such as formal, informal as well as financial and skill-related factors hindering firms' innovation performances. These include a lack of governmental R\&D policies, increasing costs of innovation and lacking internal resources at the firm level (Demirbas et al., 2011). In their qualitative study with academics and industry experts, Peksatici and Ergun (2019) find diverging institutional logics or cultures together with resulting pressures for both sides as the main barrier to effective UICs within the aviation industry in Turkey (Peksatici \& Ergun, 2019). In their study of Turkish firms and local universities, Temel and Glassman (2013) identify major obstacles preventing R\&D collaborations between the two institutions. From the perspective of firms, the most important UIC barriers are the required time of scientific research procedures, highly bureaucratic decision-making processes and administrative costs among other factors. In this regard, the authors develop a model of building awareness, building trust and experience as well as providing transition opportunities to collaborations to diminish barriers and further encourage more UICs (Temel \& Glassman, 2013).

Based on these more 'classic' administrative barriers, we assume that administrative or transaction costs as well as differences in pace for decision-making are still relevant factors inhibiting successful UICs. Therefore, we hypothesize that:

H.6 'High administrative costs of UICs' increases the barrier to using UICs for innovation. (Cost barrier)

H.7 'Differences in pace for decision-making' increases the barrier to using UICs for innovation. (Pace barrier)

\subsubsection{Perceived versus deterring barriers}

An alternative explanation of how the perception of barriers by firms might be influenced comes from D'Este et al. (2012) who study barriers to innovative activities in general. They distinguish between perceived and deterring barriers to innovation. Perceived barriers, which the authors call revealed barriers, are only perceived as barriers to innovation by firms that already engage in innovative activities because they have experienced those 
barriers. In contrast, they define deterring barriers that actually prevent firms from carrying out innovation activities in the first place and are therefore mainly experienced by non-innovative firms. This distinction has since been used by others studying firm innovativeness, finding that the firm's assessment of innovation barriers also depends on country contexts (De Fuentes et al., 2020). We use these insights on barriers for general innovative activities to critically evaluate how firms' perception of our four categories of barriers affecting UICs might differ. $R \& D$ capabilities as well as external support barriers can therefore be described as deterring barriers, as they have a strong impact on the search of collaboration partners and its implementation. They will therefore prevent UICs from forming even before the collaboration has begun. However, collaboration partner barriers and administrative barriers are barriers that require a certain knowledge of the collaboration process and might therefore be described as perceived barriers. Therefore, this distinction of perceived and deterring barriers can be helpful to bear in mind when analyzing barriers to innovative activities and interpreting potential effects. However, it is not yet clear if this distinction created to better understand innovativeness yields insights when investigating collaboration barriers.

\section{Contextual setting for innovation and UICs}

For many years, Turkey has been the leading economic and financial center between Southeastern Europe and the Middle East, and is currently transforming from an emerging to an industrialized market country (Etkin et al., 2000; Tatoglu \& Demirbag, 2008). Based on its unique location between advanced Western and emerging Eastern Markets, the country is attracting increasing numbers of FDIs and multinational enterprises (MNEs) that are locating their R\&D activities in Turkey (Ayden et al., 2018; Karabag et al., 2011). Furthermore, the country is perpetually transforming its economic structures into a more knowledgebased system, fostering innovation activities of its domestic firms and implementing measures in education as well as public and private R\&D (Bakirci, 2018; Yildirim, 2017). Nevertheless, limited R\&D activities together with a lack of technological knowledge result in low value-added of many Turkish firms, meaning that the export of high technological products remains at low levels (Yaşar, 2019). Identifying ways to increase the value-added of its domestic firms to raise productivity and move up in global value chains (GVCs) is therefore a highly important success factor for the country's future economic development. In this regard, it is relevant to understand firms' innovation strategies and their use of external resources in terms of collaboration with universities and political institutions.

For capturing the most relevant segment of R\&D-related or innovation-oriented firms for our analysis, this study focuses on a survey sample from Istanbul and the surrounding Marmara region. The majority of manufacturing clusters in Turkey are located in the central or western regions, for instance in Istanbul and its neighboring provinces (Akgüngör, 2006). In comparison to other major cities within the country, Istanbul shows by far the highest concentration of firms and headquarters (HQs) and is home to the largest number of HQs of the top 500 corporations in Turkey (Ersoy, 2018). Moreover, the city accounts for more than $45 \%$ of net value added and production profit as well as more than half of all exports nationwide (Ersoy, 2018). Furthermore, of all regions within Turkey, Istanbul displays the highest levels of scientific or R\&D-related personnel, the highest amount of technology product exports as well as the highest number of patents granted (Belgin, 2019; TUIK, 2019). With its agglomerations of knowledge-intensive industries, the city also has 
an important bridging function to globalized knowledge networks (Ersoy, 2018). In addition, the city's surrounding Marmara regions show the highest location quotient values for medium and high-technology sectors in Turkey (Çelik et al., 2019). The metropolitan area of Istanbul is thus a major hub for most innovation and R\&D-related activities of different types of firms and in particular for inward FDI of foreign MNEs, which provides an ideal setting for our study.

\section{Quantitative research method and findings}

\subsection{Survey sampling and data collection}

In order to answer our research question concerning potential barriers that might inhibit firms of using UICs for innovation we compiled the survey sample for the subsequent data analysis as follows.

Firstly, we used a database from TÜBITAK, the leading agency for funding, management and conducting research in Turkey, for identifying the most R\&D-related segment of firms in Turkey. As of 2015, this database included over 8500 firms nationwide that completed at least one R\&D project funded by TÜBITAK and of which nearly 4000 firms are located in Istanbul and the Marmara region. From this database, we compiled a new subset only involving manufacturing firms that are geographically located in Istanbul and that finalized at least three R\&D projects successfully. In result, we identified 838 firms whose general managers and $R \& D$ executives were approached to participate in our study. Consequently, we received 265 questionnaires, 40 of which we omitted due to missing values or a lack of R\&D-related activities. Overall, having an effective $26.85 \%$ (225 of 838) response rate is a satisfactory result given the topic and potential respondents. In terms of content validity of the questionnaire measures, we adopted the procedures suggested by Hair et al. (2007). Firstly, we conducted interviews with local R\&D experts from universities, technology parks, TTOs, state-level institutions and manufacturing firms about the regional innovation environment for UICs and firms' R\&D-related activities in Istanbul. Based on these findings and the extent literature review, we then developed an initial version of the questionnaire. Secondly, we revised the survey draft through discussion with other scholar experts. Finally, a pre-test of the survey was conducted with randomly selected firms and adjusted accordingly until the questionnaire reached an adequate level of clarity and maturity. The final survey took place in the first half of 2016.

\subsection{Research framework}

Overall, it is evident from our literature discussion that barriers to successful UICs can have various causes, such as a lack of information about collaboration partners or opportunities, lacking financial political support, a lack of trust, a perception of inadequately skilled collaboration partners or divergent expectations, as well as high administrative and bureaucratic burdens such as cost and time-related obstacles. In order to address the research question: 'What barriers prevent firms' use of UICs for achieving innovation?', the statistical model analyzes the effect of these barriers on the likelihood of firms not using UICs for innovation. The research framework following the hypotheses for the statistical analysis of this study is shown in Fig. 1. 


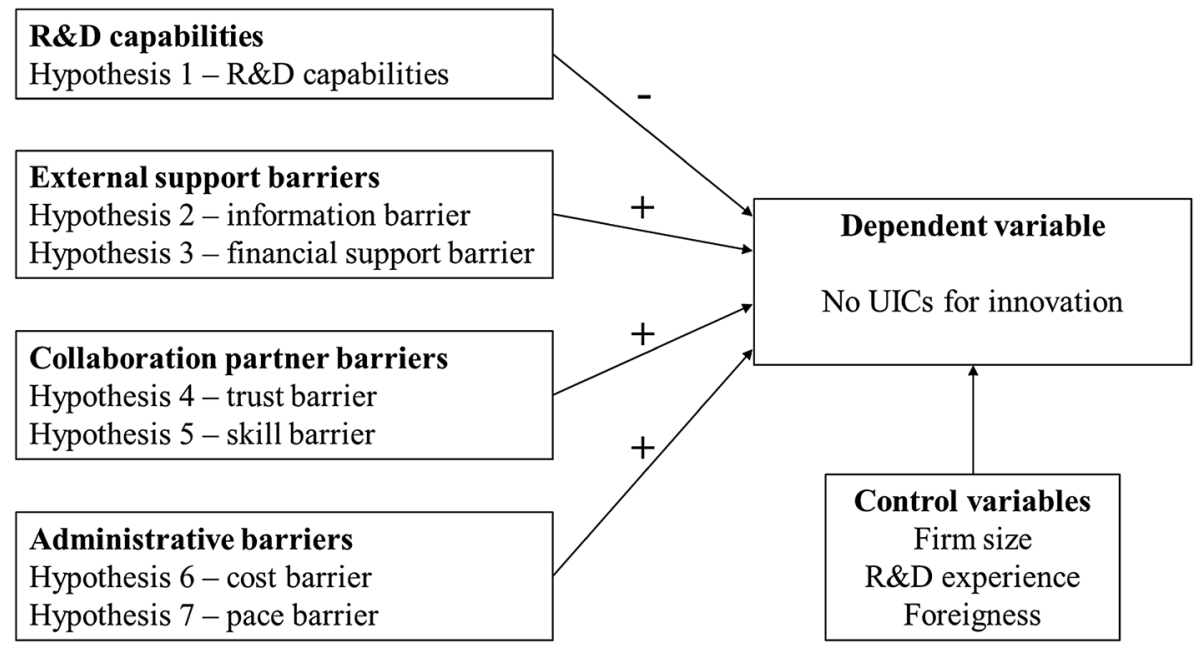

Fig. 1 Research framework. Source: own figure

\subsection{Measurement of the variables}

In the following section, the operationalization of these concepts as dependent, independent and control variables in the statistical analysis are described in detail and a summary is provided in Table 1.

The outcome or dependent variable is derived from a set of questions about firms' usage of various R\&D resources during their innovation process: 'To what extent have the following aspects been used for achieving innovation in Istanbul and the Marmara region?' The respective answers were measured on a five-point Likert scale, ranging from '1-Frequently used' to '5-Never used' regarding the frequency of using 'collaboration with scientific partners' for achieving innovation. This variable is then transformed into a binary variable to distinguish firms that do and such that do not use UICs for their innovative activities. Firms that claim to 'never' or 'almost never' use UICs are denoted as 'not using UICs for achieving innovation' which is coded as 1 while other firms that use UICs for innovative activities are coded as 0 .

The independent variable $R \& D$ capabilities is a categorical variable measured as $R \& D$ expenditure of total sales. The independent UIC barrier variables are derived from a question about different factors concerning barriers to collaboration with scientific partners: 'To what extent have the following aspects been important barriers to collaboration with regional scientific partners?'. The answers are likewise based on a five-point Likert scale, ranging in their importance levels from ' 1 -Not at all important' to '5-Very important'. Consequently, the higher the value of the selected answer, the more relevant is the barrier to UICs. The variables are derived from the following items: 'Insufficient knowledge about collaboration opportunities' as information barrier, 'Insufficient financial support or incentives for collaboration' as financial support barrier, the mean score of 'Low confidence in collaboration partners concerning handling sensitive information' and 'Low confidence in collaboration partners due to intellectual property rights' together as trust barriers, 'Inadequately skilled collaboration partners (nothing to offer)' as skill barrier, 'High bureaucracy or administration costs' as cost barrier and 'Length of time for decision making or 


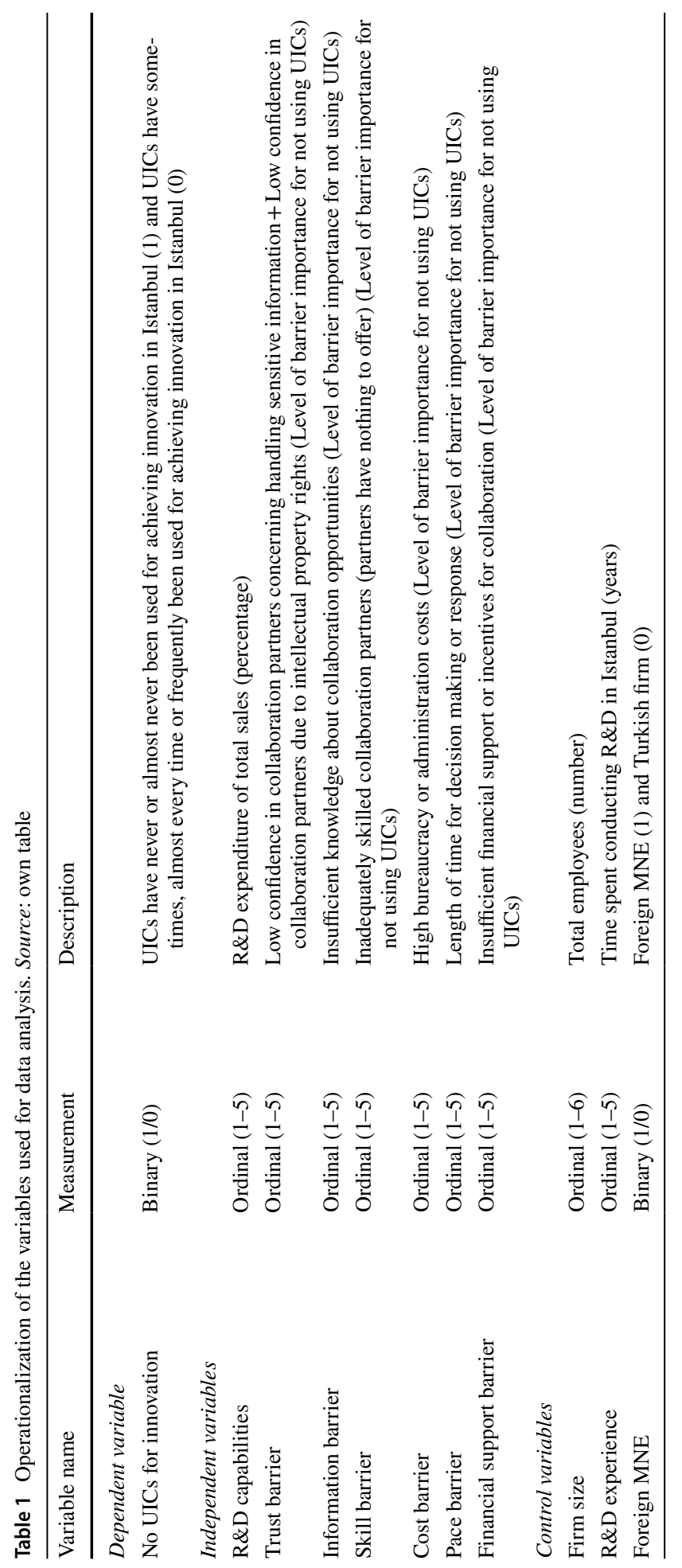


response' as pace barrier. In the analysis, we test the impact of the respective barriers on using UICs as an external knowledge source for achieving innovation. Using this approach, we are able to identify barriers that actually prevent UICs and therefore represent a bottleneck to UICs.

In addition, we used control variables to control for additional influences and test the robustness of the observed results for UIC barriers that are also measured on a five-point Likert scale. The variables $R \& D$ experience and firm size control for firms' internal $\mathrm{R} \& \mathrm{D}$ capabilities. We assume that larger and more experienced firms have more resources to use UICs for achieving innovation. Moreover, studies show that firms' size structures provide consistently explanation for differences in overcoming barriers to UICs or R\&D collaborations across all sectors (de Moraes Silva et al., 2018). The dichotomous variable foreign $M N E$ observes the influence of firms' foreign ownership, as we assume that the respective group of firms tend to collaborate more successfully with universities. These control variables are commonly used in similar studies at the firm level (Fontana et al., 2006; Laursen \& Salter, 2004; Liefner et al., 2006; Yu \& Lee, 2017).

\subsection{Data analysis}

Firm-level barriers to UICs or innovation can be considered from different angles. Perceived barriers to innovation might be discerned by successful and unsuccessful innovators (De Fuentes et al., 2020), between postponed and abandoned innovation projects (Galia \& Legros, 2004), by difficulties that prevent firms from undertaking innovation activities in the first place or differentiate between barriers that stop firms from further engaging during their innovation process (D'Este et al., 2012, 2014). In addition, Blanchard et al. (2013) highlight the importance of distinguishing between firms that either fail or do not even intend to innovate, to measure barriers to innovation performances properly. In our survey sample, we observed firms that engage in R\&D-related activities and are willing to collaborate with universities, but which either do or do not use UICs as an external knowledge source for achieving innovation.

Subsequently, logistic regression analysis is used to estimate the effects of the barriers to UICs on the outcome variable of firms that do not use UICs for achieving innovation. For this, the logistic regression models can be expressed as:

$$
P(Y i=1)=\frac{1}{1+e^{-(\alpha+X i \beta)}}
$$

Here, $\mathrm{Yi}$ is the dependent variable, which is a dummy variable with a value of zero or one, where a value of zero denotes the probability of an event not occurring rather than another denoted by one. The intercept is described as $\alpha$, and $X i$ is the vector of the independent as well as control variables, with $\beta$ as the vector of the regression parameters (Amemiya, 1981). The value of the regression coefficient $\beta$ estimates the impact of the independent on the dependent variable, where a coefficient above one increases the probability of an event occurring, while a value below one implies the opposite effect on the outcome variable. Here, the regression coefficients estimate the probability of firms that are not using UICs for achieving innovation. Coefficient results are reported as exponentiation of the $\beta$ coefficient $(\operatorname{Exp}(\beta))$, given an odds ratio of the independent variables. 


\subsection{Descriptive statistics}

Tables 2 and 3 provide a descriptive overview over the variables, differentiated between firms that use UICs for achieving innovation and firms that do not (No UICs). Table 4 provides the Spearman's rank correlation matrix of the independent and control variables for the survey. All correlation coefficients between the independent variables show positive and highly significant pairwise correlations with weak to moderate correlations (Akoglu, 2018). This shows that, as expected, all UIC barriers moderately and positively correlate among each other. In particular, both administrative barriers cost barrier and pace barrier as well as the external support barrier financial support barrier are positively correlated. Furthermore, most control variables indicate no correlation among each other or with independent variables; however, the firm size is correlated positively with the variable $R \& D$ experience. In addition, significant negative correlations of financial support barriers with firm size can be observed, indicating that large foreign firms might not assess a lack of financial political support as a relevant barrier to UICs.

\subsection{Analytic statistical results}

The subsequent results of the logistic regression analysis are reported in Table 5. In terms of hypotheses testing, model one serves as the baseline model and model two incorporates control variables to validate the effects of the independent variables.

Regarding model one, a total of five variables indicate a statistically significant impact on the outcome variable, however only two independent variables are positively related to not using UICs for achieving innovation. These are information barriers $(\operatorname{Exp}(\beta)=1.479, p<0.1)$ and financial support barriers $(\operatorname{Exp}(\beta)=1.734, p<0.05)$. Firms perceiving these types of barriers thus have a 47.9 and $73.4 \%$ higher chance of being prevented from using UICs for achieving innovation. Consequently, hypotheses two and three are accepted. Further, the variable R\&D capabilities is significantly negative related to the dependent variable shown by an exponentiated value under 1 $(\operatorname{Exp}(\beta)=0.578, p<0.05)$, which confirms hypothesis one that lower R\&D capabilities prevent from successful UIC collaboration in the innovative segment. In contrast, both variables concerning trust barriers $(\operatorname{Exp}(\beta)=0.571, p<0.05)$ and skill barriers $(\operatorname{Exp}(\beta)=0.536, p<0.01)$ have a significant negative impact on the independent variable. This means that those barriers are perceived as higher for firms that do use UICs for creating innovations. This is a highly interesting finding, as those variables are both collaboration partner barriers that indicate how firms perceived the relation to their university based partners. This finding suggests that firms that do successfully collaborate perceived trust issues and skill mismatch as higher barriers than firms that do no collaborate, indicating that these are issues that arise only during collaboration for innovation and seem not to be a concern before starting the collaboration. This finding therefore suggests that the distinction between deterring versus perceived barriers might hold for some UIC barriers as discussed by D'Este et al. (2012) or innovativeness in general, because collaboration partner barriers might indeed be perceived barriers. The other two administrative barriers, cost barriers and pace barriers, have no statistically significant effect on the outcome variable and thus seem to be less relevant for explaining which firms are prevented from using UICs for innovation.

In model two, considering the control variables, the same five independent variables still show a statistically significant impact on the outcome variable. Both variables information 
Table 2 Descriptive figures of the categorical variables. Source: own table and calculations

\begin{tabular}{|c|c|c|c|c|c|c|}
\hline & \multicolumn{2}{|c|}{ Total } & \multicolumn{2}{|c|}{ UICs } & \multicolumn{2}{|c|}{ No UICs } \\
\hline & $N$ & $\%$ & $N$ & $\%$ & $N$ & $\%$ \\
\hline \multicolumn{7}{|c|}{ Firm size (total employees) } \\
\hline$<250$ & 112 & 50.0 & 88 & 46.6 & 24 & 68.6 \\
\hline $250-499$ & 43 & 19.2 & 39 & 20.6 & 4 & 11.4 \\
\hline 500-999 & 23 & 10.3 & 20 & 10.6 & 3 & 8.6 \\
\hline 1000-1999 & 11 & 4.9 & 9 & 4.8 & 2 & 5.7 \\
\hline $2000-5000$ & 19 & 8.5 & 18 & 9.5 & 1 & 2.9 \\
\hline$>5000$ & 16 & 7.1 & 15 & 7.9 & 1 & 2.9 \\
\hline \multicolumn{7}{|c|}{$R \& D$ experience (time spent conducting $R \& D$ ) } \\
\hline$<5$ years & 39 & 17.7 & 29 & 14.4 & 10 & 31.3 \\
\hline $5-10$ years & 57 & 25.9 & 49 & 26.1 & 8 & 25.0 \\
\hline $11-20$ years & 54 & 24.5 & 50 & 26.6 & 4 & 12.5 \\
\hline $21-40$ years & 45 & 20.5 & 36 & 19.1 & 9 & 28.1 \\
\hline$>40$ years & 25 & 11.4 & 24 & 12.8 & 1 & 3.1 \\
\hline \multicolumn{7}{|c|}{$R \& D$ capabilities ( $R \& D$ expenditure of total sales) } \\
\hline$<20 \%$ & 110 & 50.5 & 83 & 45.1 & 27 & 79.4 \\
\hline $21-40 \%$ & 48 & 22.0 & 45 & 24.5 & 3 & 8.8 \\
\hline $41-60 \%$ & 28 & 12.8 & 25 & 13.6 & 3 & 8.8 \\
\hline $61-80 \%$ & 12 & 5.5 & 12 & 6.5 & 0 & 0 \\
\hline$>80 \%$ & 20 & 9.2 & 19 & 10.3 & 1 & 2.9 \\
\hline$N$ & 225 & & 190 & & 35 & \\
\hline
\end{tabular}

Table 3 Descriptive figures of the barrier variables. Source: own table and calculations

\begin{tabular}{|c|c|c|c|c|c|c|c|c|c|}
\hline \multirow[b]{2}{*}{ Barrier variables } & \multicolumn{3}{|l|}{ Total } & \multicolumn{3}{|l|}{ UICs } & \multicolumn{3}{|c|}{ No UICs } \\
\hline & $\bar{x}$ & SD & Mdn & $\overline{\mathrm{x}}$ & SD & Mdn & $\overline{\mathrm{x}}$ & SD & Mdn \\
\hline Trust barrier & 3.24 & 1.05 & 3.50 & 3.32 & 1.03 & 3.50 & 2.77 & 1.05 & 3.00 \\
\hline Information barrier & 3.32 & 1.20 & 3.00 & 3.31 & 1.17 & 3.00 & 3.33 & 1.36 & 4.00 \\
\hline Skill barrier & 3.22 & 1.18 & 3.00 & 3.32 & 1.17 & 3.00 & 2.67 & 1.11 & 3.00 \\
\hline Cost barrier & 3.31 & 1.25 & 4.00 & 3.35 & 1.21 & 4.00 & 3.03 & 1.42 & 3.00 \\
\hline Pace barrier & 3.47 & 1.21 & 4.00 & 3.48 & 1.18 & 4.00 & 3.36 & 1.39 & 4.00 \\
\hline Financial support barrier & 3.50 & 1.25 & 4.00 & 3.47 & 1.24 & 4.00 & 3.67 & 1.36 & 4.00 \\
\hline$N$ & 225 & & & 190 & & & 35 & & \\
\hline
\end{tabular}

$\overline{\mathrm{x}}$ arithmetic mean, $S D$ standard deviation, $M d n$ median

barrier $(\operatorname{Exp}(\beta)=1.572, p<0.1)$ and financial support barrier $(\operatorname{Exp}(\beta)=1.639, p<0.1)$ have a positive impact on not using UICs for achieving innovation, with a 57.2 and $63.9 \%$ higher chance respectively. In the same way, the variables trust barrier $(\operatorname{Exp}(\beta)=0.571$, $p<0.05)$ and skill barrier $(\operatorname{Exp}(\beta)=0.525, p<0.01)$ indicate a negative effect on the dependent variable. No significant impact of the variables according to hypotheses six and seven can be found. Overall, results from baseline model one are robust. 


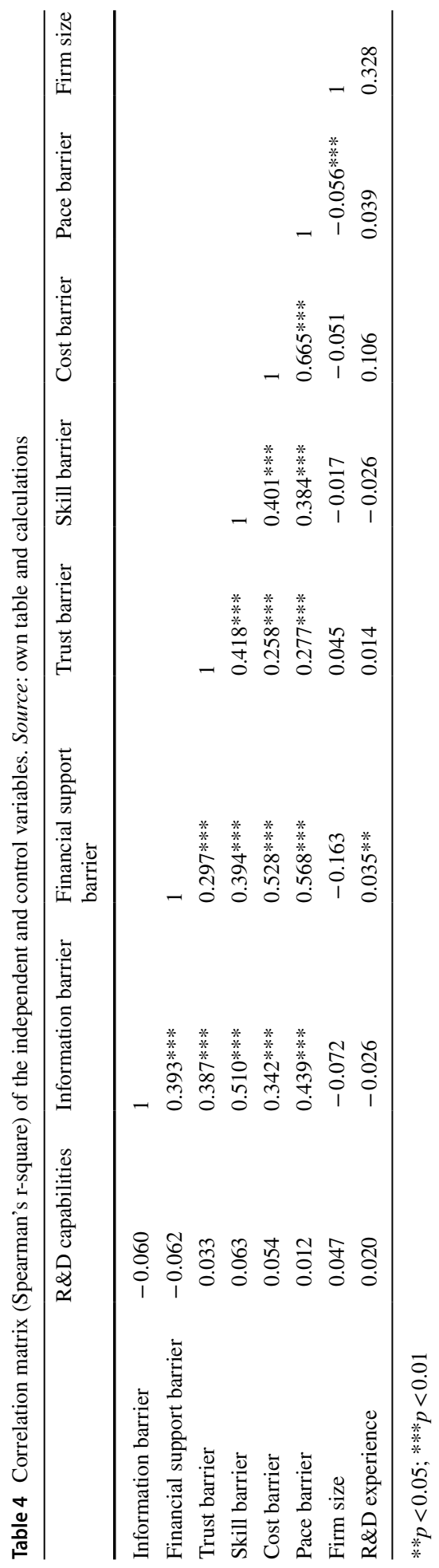


Table 5 Logistic regression with 'No UICs for innovation' as dependent variable. Source: own table and calculations
Dependent variable No UICs for innovation

(1)

(2)

\begin{tabular}{|c|c|c|}
\hline & Logit & Logit \\
\hline R\&D capabilities & $\begin{array}{l}0.578^{* *} \\
(0.340-0.872)\end{array}$ & $\begin{array}{l}0.637^{* *} \\
(0.381-0.952)\end{array}$ \\
\hline Information barrier & $\begin{array}{l}1.479^{*} \\
(0.955-2.343)\end{array}$ & $\begin{array}{l}1.572^{*} \\
(0.982-2.602)\end{array}$ \\
\hline Financial support barrier & $\begin{array}{l}1.734^{* *} \\
(1.113-2.803)\end{array}$ & $\begin{array}{l}1.639^{*} \\
(0.984-2.854)\end{array}$ \\
\hline Trust barrier & $\begin{array}{l}0.571^{* *} \\
(0.349-0.909)\end{array}$ & $\begin{array}{l}0.571^{* *} \\
(0.340-0.938)\end{array}$ \\
\hline Skill barrier & $\begin{array}{l}0.536^{\text {*** }} \\
(0.335-0.842\end{array}$ & $\begin{array}{l}0.525^{* * *} \\
(0.320-0.837)\end{array}$ \\
\hline Cost barrier & $\begin{array}{l}0.728 \\
(0.464-1.151)\end{array}$ & $\begin{array}{l}0.696 \\
(0.427-1.144)\end{array}$ \\
\hline Pace barrier & $\begin{array}{l}1.004 \\
(0593-1.710)\end{array}$ & $\begin{array}{l}1.064 \\
(0.603-1.909)\end{array}$ \\
\hline \multicolumn{3}{|l|}{ Control variables } \\
\hline Firm size & & $\begin{array}{l}0.910 \\
(0.606-1.291)\end{array}$ \\
\hline $\mathrm{R} \& \mathrm{D}$ experience & & $\begin{array}{l}0.826 \\
(0.564-1.191)\end{array}$ \\
\hline Foreign MNE & & $\begin{array}{l}0.191^{*} \\
(0.024-0.870)\end{array}$ \\
\hline Constant & 1.701 & 3.340 \\
\hline Observations & 211 & 206 \\
\hline Log likelihood & -73.239 & -65.103 \\
\hline Akaike Inf. Crit & 162.478 & 152.206 \\
\hline Model chi-square & $33.115^{* * *}$ & $37.219^{* * *}$ \\
\hline Cox and Snell r-square & 0.145 & 0.165 \\
\hline Nagelkerke r-square & 0.253 & 0.297 \\
\hline Effect size (Nagelkerke r-square) & 0.339 & 0.422 \\
\hline Hosmer and Lemeshow chi-square & 8.738 & 3.270 \\
\hline
\end{tabular}

95\%-confidence interval in parentheses

$* p<0.1 ; * * p<0.05 ; * * * p<0.01$

Concerning the control variables in model two, only foreign $M N E(\operatorname{Exp}(\beta)=0.191$, $p<0.1)$ has a statistically significant negative impact on the dependent variable. Consequently, firms being of foreign ownership are more likely to use UICs for achieving innovation. Interestingly, both firm size and $R \& D$ experience in Istanbul have no statistically significant impact.

In summary, Fig. 2 provides the results for all hypotheses tested during the logistic regression analysis. We find full support for hypotheses one, two and three. Hypotheses four and five are rejected as the variables show an interesting negative relation to the 


\section{Hypotheses \\ Result \\ R\&D capabilities \\ Hypothesis $1-R \& D$ capabilities \\ $\Rightarrow$ supported \\ External support barriers \\ Hypothesis 2 - information barrier \\ Hypothesis 3 - financial support barrier \\ $\Rightarrow$ supported \\ Collaboration partner barriers \\ Hypothesis 4 - trust barrier \\ Hypothesis 5 - skill barrier

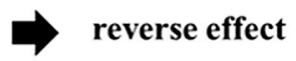 \\ Administrative barriers \\ Hypothesis 6 - cost barrier \\ Hypothesis 7 - pace barrier

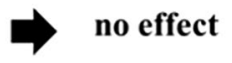

Fig. 2 Summary of results. Sources: own table

dependent variable contrary to what we would have expected from the literature. We find no evidence that would support hypotheses six and seven.

\subsection{Robustness checks}

Starting with the reliability measures reported for both models in Table 5, both models indicate a good overall fit for the chosen variables with highly significant chi-square values $(p<0.01)$, meaning that our predicted models fit significantly better for the survey sample than a null mode. Moreover, the Cox and Snell and Nagelkerke pseudo r-square values likewise indicate a good overall fit for both models. Based on the Nagelkerke r-square values, about $20 \%$ of the variance in baseline model one and about $30 \%$ in model two (with control variables) are explained. In addition, large effect sizes of both models indicate a good validity for subsequent data analysis (J. Cohen, 1992). Finally, chi-square values of the Hosmer and Lemeshow test indicate no significant differences between predicted and observed variables in both models. Consequently, another good overall fit for the independent and control variables can be assumed (Hosmer et al., 2013).

In order to account for multicollinearity in the models, we calculate the variance inflation factor (VIF) for the independent and control variables in Table 6. The results show that all values are rather low and no VIF is higher than 10 (Kutner et al., 2005) or even higher than the more strict threshold suggested by some which is 5 . This shows that multicollinearity is not a problem in the statistical models for this analysis.

However, to address any potentially remaining endogeneity issues, we use an instrumental variable as a robustness check for the impact of the independent variable information barriers. We use the variable low interest representing low interest in collaboration with scientific partners as an instrument, as this variable has a direct influence on how the firm perceives barriers to collaboration. If the company has low interest in collaborating with scientific partners, it will perceive lack of information, which scientific partners would be fitting for a collaboration, as a higher barrier because it is less motivated to invest in an 
Table 6 Variance inflation factor for independent variables. Source: own calculations

\begin{tabular}{lc}
\hline Independent variable & VIF \\
\hline R\&D capabilities & 1.024 \\
Information barrier & 1.816 \\
Financial support barrier & 2.340 \\
Trust barrier & 1.433 \\
Skill barrier & 1.611 \\
Cost barrier & 2.019 \\
Pace barrier & 2.517 \\
R\&D experience & 1.176 \\
Firm size & 1.105 \\
Foreign MNE & 1.092 \\
\hline
\end{tabular}

appropriate search strategy to overcome it. The instrumental variable is highly correlated with the variable information barriers. Moreover, this variable does not directly influence the dependent variable No UICs for innovation but only via the variable information barriers, making it a valid instrument for the robustness check (Wooldridge, 2002). We use the R package ivtools by Sjolander and Martinussen (2019) for the two-stage estimation. Moreover, we add a control function to the set of variables in the second stage model to reduce bias (Vansteelandt et al., 2011). The results in Table 7 show that using the instrument does not cause larger changes in the model. In fact, the effect size of most variables slightly increases and the statistical significance of the independent variable we used the instrument on increases. The results of this robustness check show that we do not expect any issues of endogeneity for this variable effect on the dependent variable of the model.

We also conducted a robustness check by including the independent variables as dummies in the Logit model as shown in the 'Appendix' in Table 8. The results show that the direction of the effects of all significant variables remains stable. The dummy for information barrier and $R \& D$ capabilities dummy now fall to a lower level of significance due to the reduction of information by dichotomizing the variables but the direction of the effect remains stable for both variables. The results can therefore be assumed robust.

\section{Discussion}

In the following, we are discussing the results of our survey data analysis. The statistical results show that external support barriers, in particular information barriers and financial support barriers, are the main barriers inhibiting UICs for the surveyed firms. These statistical results indicate that firms often recognize their need for R\&D-related collaborations and have distinct ideas on what to develop, but still have no or only insufficient knowledge about where to find appropriate collaboration partners at universities. These findings thus emphasize the relevance of TTOs in the RIS for initiating UICs through providing information on collaboration opportunities and hence reduce search costs for firms.

Furthermore, our findings suggest that more common or 'classic' perceived barriers between firms and universities (Bruneel et al., 2010), which are presented in our analysis as administrative barriers such as cost barriers and pace barriers, do not influence firms' usage of UICs in their innovation processes. For the surveyed firms in our sample, we find that these initial difficulties are no relevant obstacles to collaboration with universities. In 
Table 7 Robustness check with instrumental variable

\begin{tabular}{lll}
\hline & \multicolumn{2}{l}{$\begin{array}{l}\text { Dependent variable No UICs for } \\
\text { innovation }\end{array}$} \\
\cline { 2 - 3 } & $(2)$ & $(5)$ \\
& Logit & 2-stage GLM \\
\hline R\&D capabilities & $0.637^{* *}$ & $0.632^{* *}$ \\
Information barrier & $1.572^{*}$ & $1.590^{* *}$ \\
Financial support barrier & $1.639^{*}$ & $1.634^{* *}$ \\
Trust barrier & $0.571^{* *}$ & $0.597^{* *}$ \\
Skill barrier & $0.525^{* * *}$ & $0.542^{* *}$ \\
Cost barrier & 0.696 & 0.618 \\
Pace barrier & 1.064 & 1.071 \\
Firm size & 0.910 & 0.903 \\
R\&D experience & 0.826 & 0.834 \\
Foreign MNE & $0.191^{*}$ & $0.207^{*}$ \\
Constant & 3.340 & 3.642 \\
Observations & 206 & 206 \\
\hline
\end{tabular}

In model 3, the independent variable information barrier is instrumented with the variable low interest

$* p<0.1 ; * * p<0.05 ; * * * p<0.01$

addition, some barriers even have a statistically negative impact on the dependent variable. For instance, trust barriers has a significant negative impact on not using UICs for achieving innovation. This result suggests that for firms in our sample, IPR concerns do not act as a barrier to establish UICs in the first place and thus relate to findings by Bercovitz and Feldman (2007), who show evidence that firms prefer universities as external R\&D collaboration partners over other firms, particularly if IPR conflicts are perceived (Bercovitz \& Feldman, 2007). Moreover, the significantly negative relation here suggests that conversely IPR issues are only a concern for firms that already collaborate with scientific partners. In the same way, firms' perception of skill barriers has a significantly negative impact on not using UICs for achieving innovation. The skill barrier is thus perceived as higher by firms that already use UICs for innovation and does not prevent them from establishing collaborations in the first place, following the discussion on perceived versus deterring barriers for innovations. This finding shows that in-depth knowledge about the skills of the partner is only gained after the collaboration started. Therefore, the surveyed firms that do not collaborate do not perceive universities as inadequate skilled collaboration partners, while firms that do collaborate find this an issue.

In previous studies, a lack of internal resources or absorptive capacities was found to be the main barrier for firms to access external knowledge sources and establish UICs in the first place. Our results emphasize the importance of high R\&D capabilities for decreasing barriers to use UICs. In addition, we control for firms' size and their time spent conducting $\mathrm{R} \& \mathrm{D}$ in Istanbul as further determinants for absorptive capacities and successful collaboration with external partners (Fontana et al., 2006; Laursen \& Salter, 2004; Liefner et al., 
2006; Yu \& Lee, 2017). The statistical effects of firms' size and time spent conducting R\&D in Istanbul are both insignificant. This indeed is the case, as we observed both large firms and SMEs that are successful in achieving innovation and keen to engage in UICs. We cannot confirm that smaller firms are less in favor of using UICs for achieving innovation. In terms of the time spent conducting R\&D in Istanbul, the non-significant but negative impact might also be related to the mix of various firm types that have either operated in Istanbul for a long time, are young and only recently established firms, or are MNEs that have only recently invested in Turkey. The significantly negative impact of $R \& D$ capabilities on not using UICs elucidates the importance of internal R\&D resources. Additionally, the dummy variable foreign $M M E$ has a negative and significant impact on not using UICs, meaning that the probability of not using UICs in the innovation process is higher for Turkish firms and lower for foreign MNEs. These results are in contrast to findings from similar EMs or the Turkish context, in which the likelihood of universities collaborating with foreign firms' is not higher than for their domestic competitors (Beyhan \& Findık, 2014; Segarra-Blasco \& Arauzo-Carod, 2008).

\section{Conclusion and implications}

This study has focused on barriers to UICs in the EM of Turkey. In this regard, we conducted a logistic regression analysis with survey data from R\&D-related manufacturing firms in Istanbul. By doing so, we addressed the research question: 'What barriers prevent firms' use of UICs for achieving innovation?'. In this last section, we point out the limitations of our study and provide theoretical, managerial and policy implications separately.

\subsection{Limitations}

There are some limitations to the results of this study. Firstly, using Turkey as a singlecountry setting might limit the generalizability of our findings to other EMs. It would thus be helpful to conduct similar research in other EM contexts to compare the outcomes of this study and further extend the literature on UIC barriers in EMs. Secondly, the geographical focus on Istanbul as well as on a R\&D-related segment of manufacturing firms produces specific outcomes for a certain type of firm, particularly with regard to their innovation activities, UIC experience and in metropolitan regions. However, we gained important knowledge for a sub-group of firms that engage in innovation and R\&D activities and differ between using and not using UICs as external knowledge source for achieving innovation. Finally, as the definition suggests, UICs are a two-sided topic and we only focused on the statistical analysis of barriers from the perspective of firms. It is clear that obstacles to UICs are not only one-sided, but affect both firms and universities in similar ways. In this study, we were only able to obtain statistical information from the viewpoint of firms. Nevertheless, there might be differences regarding what universities or firms perceive as the main barriers and how to deal with obstacles to UICs respectively that warrant further research. A qualitative analysis with relevant stakeholders or experts from the scientific 
and political environment in Istanbul would be desirable in order to extend our understanding of UICs building upon our present findings.

\subsection{Theoretical implications}

Our findings contribute to the understanding of UIC barriers in EMs as well as to the understanding of the role of RISs for UICs in this setting. In this regard, our results reveal that the two most relevant barriers to using UICs for innovation are related to external support for UICs: a lack of information about UIC opportunities and a lack of financial support for UICs. Moreover, higher internal R\&D capabilities significantly decrease barriers to UICs. 'Classical' barriers to UICs such as cost- and pace-related barriers show no significant effect on using UICs for innovation in our survey sample. These findings indicate that commonly anticipated barriers in previous studies from the Turkish or EMs' context might be less relevant obstacles of using UICs for achieving innovation than previously assumed. For our R\&D-related segment of firms, we thus assume that firms are already aware of the requirements and potential problems of UICs and mostly suffer from underperforming RISs with potentially ineffective TTOs that would be in charge of providing information about UIC opportunities. In this regard, our findings reconfirm the high relevance of variables that rely on a regional support infrastructure for the emergence of innovation activities and UICs in EMs. In terms of insufficient financial support for UICs, the significance of governance in RISs and a proactive fostering of firms' innovation activities becomes evident. This is particularly important for firms that lack $R \& D$ capabilities, as having such internal resources significantly decreases barriers to UICs.

In terms of a lack of information about UIC opportunities, the need becomes relevant for a functioning support infrastructure with intermediary institutions at the regional level to ensure communications and interactions between firms, universities and politics (Cunningham \& Link, 2015; Uyarra, 2010). Well-functioning innovation systems with close collaborations between all actors are the main success factor for diminishing previously identified barriers of insufficient knowledge about UIC opportunities that might hinder the emergence of such. Our findings hence suggest the importance of putting intermediary or organizational structures such as TTOs in place that raise the awareness for engagement between universities' and firms' with each other. Moreover, TTOs are thus not only important to act as boundary spanner to bridge potential problems or cognitive barriers during UICs, but could play an increasingly proactive role in signaling interest and providing information about UIC opportunities towards firms as part of a supporting RISs.

Another crucial insight this study provides to the literature, is that we find significant negative effects for collaboration partner barriers relating to a lack of trust and firms' perception of inadequately skilled collaboration partners. This finding suggests that we need 
to distinguish between barriers that prevent firms from seeking or establishing collaborations with scientific partners such as the external support barriers discussed, and barriers that are only relevant for firms that are already involved in UICs and prevent efficiency of ongoing collaborations, as these might considerably differ. This is similar to the discussion on barriers to innovative activities distinguishing between perceived and deterring barriers by D'Este et al. (2012) as well as recent findings by De Fuentes et al. (2020), and might be relevant for the context of UICs as well. Therefore, future studies should pay attention to differentiate between barriers in ex ante, early and mature stages of UICs in order to differentiate which barriers actually deter firms from collaborating. Moreover, more qualitative evidence is needed in order to assess if and how the concept of perceived and deterring barriers can be applied to research on collaboration barriers.

\subsection{Managerial implications}

Based on the firm-level evidence of this study, we are able to provide suggestions for managers to deal with barriers that might inhibit the use of UICs for achieving innovation. A main result of our analysis is that a lack of information about collaboration opportunities acts as a significant barrier, impeding UICs. In relation to this result, Fontana et al. (2006) highlight the importance of firms' openness to their external environment. This can be measured by a process involving the initial implementation of search strategies for potential collaborations, a subsequent in-depth screening to identify the best UIC opportunities, and a final signaling stage to convince prospective partners (Fontana et al., 2006). Developing strategies to identify potential collaboration partners are thus valuable suggestions for managers of our survey as well. Although the signaling of UIC opportunities or joint R\&D projects is an associated task of universities or TTOs initially, firms likewise need to play a much more active role in searching for and screening of UIC opportunities as well as signaling interest to establish UICs consequently.

In addition, firms should continuously invest in highly skilled human capital and R\&Drelated personnel in particular, as these employees not only provide the firms with certain skills and knowledge, but are also a key success factor for identifying and establishing UICs, and hence for consistently overcoming major barriers to innovation activities (D'Este et al., 2014; De Fuentes et al., 2020). This is also reflected in our results that having $R \& D$ capabilities significantly decreases the barrier to use UICs for achieving innovation. Consequently, firms that invest highly in their internal R\&D capabilities and personnel are less likely to face barriers to UICs. This also involves the search for financial 
support from political institutions, particularly if internal resources or R\&D capabilities are scarce.

\subsection{Policy implications}

The statistically positive impact of the financial support barrier indicates quite clear policy implications, however, financial support for UICs are not only relevant as a direct support measure to foster UICs. In this respect, Özçelik and Taymaz (2008) likewise show that public $R \& D$ support initiate more private $R \& D$ investments or $R \& D$ expenditures at the firm level, particularly for smaller firms and for EM contexts (Özçelik \& Taymaz, 2008). Therefore, public R\&D spending can simultaneously bolster firms' internal capabilities or absorptive capacities in the first place, enabling them to increasingly make use of external technologies or knowledge sources. This is particularly important as we find evidence that firms' $R \& D$ capabilities have a considerable positive effect to reduce UIC barriers. Therefore, it is highly important that policies reduce firms' perception of innovation costs to foster R\&D investments at firm level and increase capacity building, particularly of domestic firms (Santiago et al., 2017). In addition, political institutions should not only increase the awareness of public support, but most notably improve the conditions for accessing public incentives, for instance through reducing bureaucracy and training for governmental staff (De Fuentes et al., 2020).

In addition, we observe information barriers as another highly relevant barrier that has an impeding effect on the use of UICs for innovation. In result, this calls for direct policy support or directing universities' attention to considering the high relevance of TTOs for UICs, as it would be the TTOs task to provide this information to firms. The creation as well as further support of TTOs would be a crucial strategy to pursue in the future, particularly as firms seem to have insufficient knowledge about collaboration opportunities. TTOs can be of great help in this regard, as to signaling interest in UICs towards firms, pointing out collaboration possibilities, actively approach firms and provide dependability during the collaboration phase. Consequently, developing the marketing skills of TTOs' personnel might be of great help in finding external collaboration partners as well as purchasers or users of applied scientific knowledge.

Overall, the key elements for future economic development within EMs is a mix of knowledge sources that are external to firms. Therefore, political support in the form of bringing firms and universities together and providing information about UIC opportunities are highly relevant success factors. In this regard, providing collaboration platforms and networking events for universities and industrial firms or creating online platforms to match overlapping research interests of institutions can be a very helpful policy assistance concerning this matter.

\section{Appendix}

See Table 8. 
Table 8 Robustness check with independent variables as dummies

\begin{tabular}{|c|c|}
\hline & $\begin{array}{l}\text { Dependent variable } \\
\text { No UICs for innova- } \\
\text { tion } \\
(6) \\
\text { Logit }\end{array}$ \\
\hline R\&D capabilities dummy & $\begin{array}{l}0.157^{*} \\
(0.008-0.841)\end{array}$ \\
\hline Information barrier dummy & $\begin{array}{l}1.718 \\
(0.673-4.486)\end{array}$ \\
\hline Financial support barrier dummy & $\begin{array}{l}4.568^{* * *} \\
(1.717-13.352)\end{array}$ \\
\hline Trust barrier dummy & $\begin{array}{l}0.335^{* *} \\
(0.127-0.827)\end{array}$ \\
\hline Skill barrier dummy & $\begin{array}{l}0.207^{\text {*** }} \\
(0.066-0.581)\end{array}$ \\
\hline Cost barrier dummy & $\begin{array}{l}0.739 \\
(0.263-2.087)\end{array}$ \\
\hline Pace barrier dummy & $\begin{array}{l}0.844 \\
(0.291-2.457)\end{array}$ \\
\hline Constant & 0.202 \\
\hline Observations & 211 \\
\hline Log Likelihood & -73.380 \\
\hline Akaike Inf. Crit & 162.759 \\
\hline
\end{tabular}

95\%-confidence interval in parentheses

${ }^{*} p<0.1 ; * * p<0.05 ; * * * p<0.01$

Acknowledgements We greatly appreciate financial support for research stays in Turkey from the German Academic Exchange Service. Special thanks to Professor Ekrem Tatoğlu for survey sampling, data collection and very helpful discussions. Many thanks to the anonymous reviewers for their very helpful comments and suggestions. Special thanks to Professor Ingo Liefner for his important feedback and suggestions. Furthermore, thanks to our student assistant Jana Almstedt for data cleaning. Last but not least, thanks to Zoë Vercelli and Kerry Jago for language editing.

Funding Open Access funding enabled and organized by Projekt DEAL. Timo Kleiner-Schaefer greatly appreciates financial support for research stays in Turkey from the German Academic Exchange Service (Deutscher Akademischer Austauschdienst).

\section{Declarations}

Conflict of interest The authors declare that they have no conflict of interest.

Availability of data and material Research data are not shared. The data are not publicly available due to privacy or ethical restrictions.

Open Access This article is licensed under a Creative Commons Attribution 4.0 International License, which permits use, sharing, adaptation, distribution and reproduction in any medium or format, as long as you give appropriate credit to the original author(s) and the source, provide a link to the Creative Commons licence, and indicate if changes were made. The images or other third party material in this article 
are included in the article's Creative Commons licence, unless indicated otherwise in a credit line to the material. If material is not included in the article's Creative Commons licence and your intended use is not permitted by statutory regulation or exceeds the permitted use, you will need to obtain permission directly from the copyright holder. To view a copy of this licence, visit http://creativecommons.org/licenses/by/4.0/.

\section{References}

Abreu, M. (2011). Absorptive Capacity in a Regional Context. In P. Cooke, B. Asheim, R. Boschma, R. Martin, D. Schwartz, \& F. Tödtling (Eds.), Handbook of Regional Innovation and Growth. pp. 211221. Edward Elgar Publishing. https://doi.org/10.4337/9780857931504

Agrawal, A. K. (2001). University-to-industry knowledge transfer: Literature review and unanswered questions. International Journal of Management Reviews, 3(4), 285-302. https://doi.org/10.1111/14682370.00069

Akgüngör, S. (2006). Geographic concentrations in Turkey's manufacturing industry: Identifying regional highpoint clusters. European Planning Studies, 14(2), 169-197. https://doi.org/10.1080/0965431050 0418002

Akoglu, H. (2018). User's guide to correlation coefficients. Turkish Journal of Emergency Medicine, 18(3), 91-93. https://doi.org/10.1016/j.tjem.2018.08.001

Albuquerque, E., Suzigan, W., Kruss, G., \& Lee, K. (2015). Developing national systems of innovation: University-industry interactions in the Global South. Edward Elgar Publishing. https://doi.org/10. 4337/9781784711108

Amemiya, T. (1981). Qualitative response models: A survey. Journal of Economic Literature, 19(4), 1483-1536.

Ankrah, S., \& AL-Tabbaa, O. (2015). Universities-industry collaboration: A systematic review. Scandinavian Journal of Management, 31(3), 387-408. https://doi.org/10.1016/j.scaman.2015.02.003

Antonioli, D., Marzucchi, A., \& Savona, M. (2017). Pain shared, pain halved? Cooperation as a coping strategy for innovation barriers. Journal of Technology Transfer, 42(4), 841-864. https://doi.org/10.1007/ s10961-016-9545-9

Aristei, D., Vecchi, M., \& Venturini, F. (2016). University and inter-firm R\&D collaborations: Propensity and intensity of cooperation in Europe. The Journal of Technology Transfer, 41(4), 841-871. https:// doi.org/10.1007/s10961-015-9403-1

Aycan, Z. (2001). Human resource management in Turkey - Current issues and future challenges. International Journal of Manpower, 22(3), 252-260. https://doi.org/10.1108/01437720110398347

Ayden, Y., Demirbag, M., \& Tatoglu, E. (2018). Turkish multinationals: Market entry and post-acquisition strategy. Palgrave Macmillan.

Bakirci, F. (2018). Knowledge and Innovation Economy: An Evaluation of Turkey. In Ü. Bakirci, F., Heupel, Th., Kocagöz, O., Özen (Ed.), German-Turkish Perspectives on IT and Innovation Management. FOM-Edition. pp. 21-42. Springer Gabler.

Barney, J. (1991). Firm resources and sustained competitive advantage. Journal of Management, 17(1), 99-120. https://doi.org/10.1177/014920639101700108

Bastos, A. P., Serra, M., Almeida, L., \& Diniz, M. J. (2014). University-enterprise partnerships in the Brazilian Amazon: Obstacles, dilemmas and challenges. Transnational Corporations Review, 6(1), 71-85. https://doi.org/10.1080/19186444.2014.11658382

Becker, W., \& Dietz, J. (2004). R\&D cooperation and innovation activities of firms - Evidence for the German manufacturing industry. Research Policy, 33(2), 209-223. https://doi.org/10.1016/j.respol.2003. 07.003

Bekkers, R., \& Bodas-Freitas, I.-M. (2008). Analysing knowledge transfer channels between universities and industry: To what degree do sectors also matter? Research Policy, 37(10), 1837-1853. https://doi. org/10.1016/j.respol.2008.07.007

Belgin, O. (2019). Analysing R\&D efficiency of Turkish regions using data envelopment analysis. Technology Analysis \& Strategic Management, 31(11), 1341-1352. https://doi.org/10.1080/09537325.2019. 1613521

Bercovitz, J. E. L., \& Feldman, M. P. (2007). Fishing upstream: Firm innovation strategy and university research alliances. Research Policy, 36(7), 930-948. https://doi.org/10.1016/j.respol.2007.03.002

Beyhan, B., \& Cetindamar, D. (2011). No escape from the dominant theories: The analysis of intellectual pillars of technology management in developing countries. Technological Forecasting and Social Change, 78(1), 103-115. https://doi.org/10.1016/j.techfore.2010.10.001 
Beyhan, B., \& Fındık, D. (2014). Firma yenilik stratejisi ve üniversite-sanayi işbirliği: Türkiye üzerine bir çalışma. Iktisat Işletme Ve Finans, 29(342), 71-102. https://doi.org/10.3848/iif.2014.342.4205

Beyhan, B., \& Rickne, A. (2015). Motivations of academics to interact with industry: The case of nanoscience. International Journal of Technology Management, 68(3-4), 159-175. https://doi.org/10.1504/ IJTM.2015.069663

Bjerregaard, T. (2010). Industry and academia in convergence: Micro-institutional dimensions of R\&D collaboration. Technovation, 30(2), 100-108. https://doi.org/10.1016/j.technovation.2009.11.002

Bjursell, C., \& Engström, A. (2019). A Lewinian approach to managing barriers to university-industry collaboration. Higher Education Policy, 32(1), 129-148. https://doi.org/10.1057/s41307-017-0074-4

Blanchard, P., Huiban, J. P., Musolesi, A., \& Sevestre, P. (2013). Where there is a will, there is a way? Assessing the impact of obstacles to innovation. Industrial and Corporate Change, 22(3), 679-710. https://doi.org/10.1093/icc/dts027

Blomström, M., \& Kokko, A. (1998). Multinational corporations and spillovers. Journal of Economic Surveys, 12(3), 247-277. https://doi.org/10.1111/1467-6419.00056

Broström, A. (2010). Working with distant researchers-Distance and content in university-industry interaction. Research Policy, 39(10), 1311-1320. https://doi.org/10.1016/j.respol.2010.09.002

Bruneel, J., D'Este, P., \& Salter, A. (2010). Investigating the factors that diminish the barriers to universityindustry collaboration. Research Policy, 39(7), 858-868. https://doi.org/10.1016/j.respol.2010.03.006

Çelik, N., Akgüngör, S., \& Kumral, N. (2019). An assessment of the technology level and knowledge intensity of regions in Turkey. European Planning Studies, 27(5), 952-973. https://doi.org/10.1080/09654 313.2019.1579301

Cetindamar, D., \& Ulusoy, G. (2008). Innovation performance and partnerships in manufacturing firms in Turkey. Journal of Manufacturing Technology Management, 19(3), 332-345. https://doi.org/10.1108/ 17410380810853768

Cetindamar, D., Wasti, S. N., Ansal, H., \& Beyhan, B. (2009). Does technology management research diverge or converge in developing and developed countries? Technovation, 29(1), 45-58. https://doi. org/10.1016/j.technovation.2008.04.002

Chari, M. D. R. (2015). An Integrated Model of Upgrading and Catchup by Emerging Economy Firms. In L. Tihanyi, E. R. Banalieva, T. M. Devinney, \& T. Pedersen (Eds.), Emerging Economies and Multinational Enterprises. pp. 327-349. Emerald Group Publishing Limited. https://doi.org/10.1108/ S1571-502720150000028015

Chatterjee, D., \& Sankaran, B. (2015). Commercializing academic research in emerging economies: Do organizational identities matter? Science and Public Policy, 42(5), 599-613. https://doi.org/10.1093/ scipol/scu076

Chesbrough, H. W. (2003). Open Innovation: The new imperative for creating and profiting from technology. Harvard Business Press. Harvard Business School Publishing Corporation.

Chesbrough, H. W. (2010). Business model innovation: Opportunities and barriers. Long Range Planning, 43(2-3), 354-363. https://doi.org/10.1016/j.lrp.2009.07.010

Ciritcioğlu, H. H., Aydın, M., \& Şenol, S. (2016). A case study of university-industry cooperation. Mugla Journal of Science and Technology, 2(2), 89-95. https://doi.org/10.22531/muglajsci.283625

Cohen, J. (1992). Statistical power analysis. Current Directions in Psychological Science, 1(3), 98-101. https://doi.org/10.1111/1467-8721.ep10768783

Cohen, W. M., \& Levinthal, D. A. (1989). Innovation and learning: The two faces of R\&D. The Economic Journal, 99(397), 569-596. https://doi.org/10.2307/2233763

Cohen, W. M., \& Levinthal, D. A. (1990). Absorptive capacity: A new perspective on learning and innovation. Administrative Science Quarterly, 35(1), 128-152. https://doi.org/10.2307/2393553

Collings, D. G., Demirbag, M., Mellahi, K., \& Tatoglu, E. (2010). Strategic orientation, human resource management practices and organizational outcomes: Evidence from Turkey. International Journal of Human Resource Management, 21(14), 2589-2613. https://doi.org/10.1080/09585192.2010.523577

Cooke, P., Uranga, M. G., \& Etxebarria, G. (1997). Regional innovation systems: Institutional and organisational dimensions. Research Policy, 26(4-5), 475-491. https://doi.org/10.1016/s0048-7333(97) 00025-5

Cooke, P., Uranga, M. G., \& Etxebarria, G. (1998). Regional systems of innovation: An evolutionary perspective. Environment and Planning a: Economy and Space, 30(9), 1563-1584. https://doi.org/10. 1068/a301563

Crescenzi, R., Filippetti, A., \& Iammarino, S. (2017). Academic inventors: Collaboration and proximity with industry. The Journal of Technology Transfer, 42(4), 730-762. https://doi.org/10.1007/ s10961-016-9550-z 
Cunningham, J. A., \& Link, A. N. (2015). Fostering university-industry R\&D collaborations in European Union countries. International Entrepreneurship and Management Journal, 11(4), 849-860. https:// doi.org/10.1007/s11365-014-0317-4

D'Este, P., Guy, F., \& Iammarino, S. (2013). Shaping the formation of university-industry research collaborations: What type of proximity does really matter? Journal of Economic Geography, 13(4), 537-558. https://doi.org/10.1093/jeg/lbs010

D'Este, P., \& Iammarino, S. (2010). The spatial profile of university-business research partnerships. Papers in Regional Science, 89(2), 335-350. https://doi.org/10.1111/j.1435-5957.2010.00292.x

D’Este, P., Iammarino, S., Savona, M., \& Von Tunzelmann, N. (2012). What hampers innovation? Revealed barriers versus deterring barriers. Research Policy, 41(2), 482-488. https://doi.org/10.1016/j.respol. 2011.09.008

D'Este, P., \& Patel, P. (2007). University-industry linkages in the UK: What are the factors underlying the variety of interactions with industry? Research Policy, 36(9), 1295-1313. https://doi.org/10.1016/j. respol.2007.05.002

D'Este, P., \& Perkmann, M. (2011). Why do academics engage with industry? The entrepreneurial university and individual motivations. Journal of Technology Transfer, 36(3), 316-339. https://doi.org/10. 1007/s10961-010-9153-Z

D'Este, P., Rentocchini, F., \& Vega-Jurado, J. (2014). The role of human capital in lowering the barriers to engaging in innovation: Evidence from the Spanish innovation survey. Industry and Innovation. Taylor and Francis. https://doi.org/10.1080/13662716.2014.879252

De Fuentes, C., \& Dutrénit, G. (2016). Geographic proximity and university-industry interaction: The case of Mexico. Journal of Technology Transfer, 41(2), 329-348. https://doi.org/10.1007/ s10961-014-9364-9

De Fuentes, C., Santiago, F., \& Temel, S. (2020). Perception of innovation barriers by successful and unsuccessful innovators in emerging economies. The Journal of Technology Transfer, 45(4), 1283-1307. https://doi.org/10.1007/s10961-018-9706-0

de Moraes Silva, D. R., Furtado, A. T., \& Vonortas, N. S. (2018). University-industry R\&D cooperation in Brazil: A sectoral approach. Journal of Technology Transfer, 43(2), 285-315. https://doi.org/10.1007/ s10961-017-9566-Z

de Wit-de Vries, E., Dolfsma, W. A., van der Windt, H. J., \& Gerkema, M. P. (2019). Knowledge transfer in university-industry research partnerships: A review. The Journal of Technology Transfer, 44(4), 1236-1255. https://doi.org/10.1007/s10961-018-9660-x

Demirbas, D., Hussain, J. G., \& Matlay, H. (2011). Owner-managers' perceptions of barriers to innovation: Empirical evidence from Turkish SMEs. Journal of Small Business and Enterprise Development, 18(4), 764-780. https://doi.org/10.1108/14626001111179794

Doutriaux, J. (2003). University-industry linkages and the development of knowledge clusters in Canada. Local Economy: THe Journal of the Local Economy Policy Unit, 18(1), 63-79. https://doi. org/10.1080/0269094032000073843

Eisenhardt, K. M., \& Martin, J. A. (2000). Dynamic capabilities: What are they? Strategic Management Journal, 21(10-11), 1105-1121. https://doi.org/10.1002/1097-0266(200010/11)21:10/11\%3c110 5::AID-SMJ133\%3e3.0.CO;2-E

Ersoy, A. (2018). Turkey: An economic geography. I.B. Tauris and Co., Ltd.

Etkin, L. P., Helms, M. M., Turkkan, U., \& Morris, D. J. (2000). The economic emergence of Turkey. European Business Review, 12(2), 64-75. https://doi.org/10.1108/09555340010318655

Etzkowitz, H., De Mello, J. M. C., \& Almeida, M. (2005). Towards “meta-innovation" in Brazil: The evolution of the incubator and the emergence of a triple helix. Research Policy, 34(4), 411-424. https://doi.org/10.1016/j.respol.2005.01.011

Etzkowitz, H., \& Leydesdorff, L. (2000). The dynamics of innovation: From national systems and "mode 2" to a Triple Helix of university-industry-government relations. Research Policy, 29(2), 109-123. https://doi.org/10.1016/S0048-7333(99)00055-4

Etzkowitz, H., Webster, A., Gebhardt, C., \& Terra, B. R. C. (2000). The future of the university and the university of the future: Evolution of ivory tower to entrepreneurial paradigm. Research Policy, 29(2), 313-330. https://doi.org/10.1016/S0048-7333(99)00069-4

Eun, J. H., Lee, K., \& Wu, G. (2006). Explaining the "University-run enterprises" in China: A theoretical framework for university-industry relationship in developing countries and its application to China. Research Policy, 35(9), 1329-1346. https://doi.org/10.1016/j.respol.2006.05.008

Figueiredo, P. N., \& Piana, J. (2021). Technological learning strategies and technology upgrading intensity in the mining industry: Evidence from Brazil. The Journal of Technology Transfer, 46, 629659. https://doi.org/10.1007/s10961-020-09810-9 
Filippetti, A., \& Savona, M. (2017). University-industry linkages and academic engagements: Individual behaviours and firms' barriers. Introduction to the special section. The Journal of Technology Transfer, 42(4), 719-729. https://doi.org/10.1007/s10961-017-9576-X

Findık, D., \& Beyhan, B. (2015). The impact of external collaborations on firm innovation performance: Evidence from Turkey. Procedia - Social and Behavioral Sciences, 195, 1425-1434. https://doi. org/10.1016/j.sbspro.2015.06.439

Fontana, R., Geuna, A., \& Matt, M. (2006). Factors affecting university-industry R\&D projects: The importance of searching, screening and signalling. Research Policy, 35(2), 309-323. https://doi. org/10.1016/j.respol.2005.12.001

Galia, F., \& Legros, D. (2004). Complementarities between obstacles to innovation: Evidence from France. Research Policy, 33(8), 1185-1199. https://doi.org/10.1016/j.respol.2004.06.004

Garcia, R., Araújo, V., Mascarini, S., Santos, E. G., \& Costa, A. R. (2019). How the benefits, results and barriers of collaboration affect university engagement with industry. Science and Public Policy, 46(3), 347-357. https://doi.org/10.1093/scipol/scy062

Giaretta, E. (2014). The trust "builders" in the technology transfer relationships: An Italian science park experience. Journal of Technology Transfer, 39(5), 675-687. https://doi.org/10.1007/ s10961-013-9313-z

Gilsing, V., Bekkers, R., Bodas-Freitas, I.-M., \& van der Steen, M. (2011). Differences in technology transfer between science-based and development-based industries: Transfer mechanisms and barriers. Technovation, 31(12), 638-647. https://doi.org/10.1016/j.technovation.2011.06.009

Görg, H., \& Greenaway, D. (2004). Much ado about nothing? Do domestic firms really benefit from foreign direct investment? The World Bank Research Observer, 19(2), 171-198. https://doi.org/10. 1093/wbro/lkh019

Guégan, D., Hassani, B. K., \& Zhao, X. (2014). Emerging countries sovereign rating adjustment using market information: Impact on financial institutions' investment decisions. In Emerging Markets and the Global Economy. pp. 17-49. Elsevier. https://doi.org/10.1016/B978-0-12-411549-1. 00002-8

Guerrero, M., \& Urbano, D. (2017). The impact of Triple Helix agents on entrepreneurial innovations' performance: An inside look at enterprises located in an emerging economy. Technological Forecasting and Social Change, 119, 294-309. https://doi.org/10.1016/j.techfore.2016.06.015

Guerrero, M., Urbano, D., \& Herrera, F. (2019). Innovation practices in emerging economies: Do university partnerships matter? Journal of Technology Transfer, 44(2), 615-646. https://doi.org/10. 1007/s10961-017-9578-8

Hair, J. F., Money, A. H., Samouel, P., \& Page, M. (2007). Research methods for business. Education + Training. John Wiley and Sons. https://doi.org/10.1108/et.2007.49.4.336.2

Hall, B. H., Link, N. A., \& Scott, T. J. (2001). Barriers inhibiting industry from partnering with universities: Evidence from the advanced technology program. Journal of Technology Transfer, 26, 87-98. https:// doi.org/10.1023/A:1007888312792

Hosmer, D. W., Lemeshow, S., \& Sturdivant, R. X. (2013). Applied logistic regression. 3rd Ed. Wiley. Doi: https://doi.org/10.1002/9781118548387

Jormanainen, I., \& Koveshnikov, A. (2012). International activities of emerging market firms: A critical assessment of research in top international management journals. Management International Review, 52(5), 691-725. https://doi.org/10.1007/s11575-011-0115-y

Kanama, D., \& Nishikawa, K. (2017). What type of obstacles in innovation activities make firms access university knowledge? An empirical study of the use of university knowledge on innovation outcomes. Journal of Technology Transfer, 42(1), 141-157. https://doi.org/10.1007/s10961-015-9459-y

Karabag, S. F., Tuncay-Celikel, A., \& Berggren, C. (2011). The limits of R\&D internationalization and the importance of local initiatives: Turkey as a critical case. World Development, 39(8), 1347-1357. https://doi.org/10.1016/j.worlddev.2010.12.012

Kaufmann, A., \& Tödtling, F. (2001). Science-industry interaction in the process of innovation: The importance of boundary-crossing between systems. Research Policy, 30(5), 791-804. https://doi.org/10. 1016/S0048-7333(00)00118-9

Kim, C.-S., \& Inkpen, A. C. (2005). Cross-border R\&D alliances, absorptive capacity and technology learning. Journal of International Management, 11(3), 313-329. https://doi.org/10.1016/j.intman.2005.06. 002

Kleiner-Schäfer, T., \& Liefner, I. (2021). Innovation success in an emerging economy: A comparison of R\&D-oriented companies in Turkey. Growth and Change, 52(2), 963-989. https://doi.org/10.1111/ grow. 12479 
Kotabe, M., Jiang, C. X., \& Murray, J. Y. (2011). Managerial ties, knowledge acquisition, realized absorptive capacity and new product market performance of emerging multinational companies: A case of China. Journal of World Business, 46(2), 166-176. https://doi.org/10.1016/j.jwb.2010.05.005

Kruss, G., \& Visser, M. (2017). Putting university-industry interaction into perspective: A differentiated view from inside South African universities. The Journal of Technology Transfer, 42(4), 884-908. https://doi.org/10.1007/s10961-016-9548-6

Kumar, V., Kumar, U., \& Persaud, A. (1999). Building technological capability through importing technology : The Case of Indonesian manufacturing industry. Journal of Technology Transfer, 24, 81-96. https://doi.org/10.1023/A:1007728921126

Kutner, M., Nachtsheim, C., Neter, J., \& Li, W. (2005). Applied Statistical Linear Models. McGraw Hill.

Lall, S. (2000). Technological change and industrialization in the asian newly industrializing economies: Achievements and challenges. In L. Kim \& R. R. Nelson (Eds.), Technology, learning, and innovation: Experiences of newly industrializing economies. pp. 13-68. Cambridge University Press. Doi: https://doi.org/10.4337/9781781950555.00014

Laursen, K., Reichstein, T., \& Salter, A. (2011). Exploring the effect of geographical proximity and university quality on university-industry collaboration in the United Kingdom. Regional Studies, 45(4), 507-523. https://doi.org/10.1080/00343400903401618

Laursen, K., \& Salter, A. (2004). Searching high and low: What types of firms use universities as a source of innovation? Research Policy, 33(8), 1201-1215. https://doi.org/10.1016/j.respol.2004.07.004

Lee, K. (2019). The art of economic catch-up: Barriers, detours and leapfrogging in innovation systems. Cambridge, United Kingdom; New York, NY; Port Melbourne, VIC; New Delhi; Singapore: Cambridge University Press. https://doi.org/10.1017/9781108588232

Liefner, I. (2013). Explaining innovation and regional development in China: How much can we learn from applying established Western theories? In I. Liefner \& Y. D. Wei (Eds.), Innovation and regional development in China. pp. 21-40. Routledge. https://doi.org/10.4324/9780203106754

Liefner, I., Hennemann, S., \& Xin, L. (2006). Cooperation in the innovation process in developing countries: empirical evidence from Zhongguancun, Beijing. Environment and Planning a: Economy and Space, 38(1), 111-130. https://doi.org/10.1068/a37343

Lin, C., Tan, B., \& Chang, S. (2002). The critical factors for technology absorptive capacity. Industrial Management and Data Systems, 102(6), 300-308. https://doi.org/10.1108/02635570210431993

Lööf, H., \& Broström, A. (2008). Does knowledge diffusion between university and industry increase innovativeness? The Journal of Technology Transfer, 33(1), 73-90. https://doi.org/10.1007/ s10961-006-9001-3

Lopes, J., \& Lussuamo, J. (2021). Barriers to university-industry cooperation in a developing region. Journal of the Knowledge Economy, 12(3), 1019-1035. https://doi.org/10.1007/s13132-020-00646-0

Mascarenhas, C., Ferreira, J. J., \& Marques, C. (2018). University-industry cooperation: A systematic literature review and research agenda. Science and Public Policy, 45(5), 708-718. https://doi.org/ 10.1093/scipol/scy003

Mathews, J. A., \& Hu, M.-C. (2007). Enhancing the role of universities in building national innovative capacity in Asia: The case of Taiwan. World Development, 35(6), 1005-1020. https://doi.org/10. 1016/j.worlddev.2006.05.012

Muscio, A., \& Pozzali, A. (2013). The effects of cognitive distance in university-industry collaborations: Some evidence from Italian universities. The Journal of Technology Transfer, 38(4), 486-508. https://doi.org/10.1007/s10961-012-9262-y

Muscio, A., \& Vallanti, G. (2014). Perceived obstacles to university-industry collaboration: Results from a qualitative survey of Italian academic departments. Industry and Innovation, 21(5), 410-429. https://doi.org/10.1080/13662716.2014.969935

Nielsen, U. B., Hannibal, M., \& Larsen, N. N. (2018). Reviewing emerging markets: Context, concepts and future research. International Journal of Emerging Markets, 13(6), 1679-1698. https://doi. org/10.1108/IJoEM-10-2017-0416

Nsanzumuhire, S. U., \& Groot, W. (2020). Context perspective on university-industry collaboration processes: A systematic review of literature. Journal of Cleaner Production, 258, 120861. https://doi. org/10.1016/j.jclepro.2020.120861

Oliver, A. L., Montgomery, K., \& Barda, S. (2020). The multi-level process of trust and learning in university-industry innovation collaborations. Journal of Technology Transfer, 45(3), 758-779. https://doi.org/10.1007/s10961-019-09721-4

Özçelik, E., \& Taymaz, E. (2008). R\&D support programs in developing countries: The Turkish experience. Research Policy, 37(2), 258-275. https://doi.org/10.1016/j.respol.2007.11.001

Pavitt, K. (1990). What we know about the strategic management of technology. California Management Review, 32(3), 17-26. https://doi.org/10.2307/41166614 
Peksatici, Ö., \& Ergun, H. S. (2019). The gap between academy and industry - A qualitative study in Turkish aviation context. Journal of Air Transport Management, 79, 101687. https://doi.org/10. 1016/j.jairtraman.2019.101687

Prahalad, C. K., \& Hamel, G. (1990). The core competence and the corporation. Harvard Business Review, (May-June 1990), pp. 79-91.

Ramamurti, R. (2016). Internationalization and innovation in emerging markets. Strategic Management Journal, 37(13), E74-E83. https://doi.org/10.1002/smj.2553

Ramamurti, R., \& Singh, J. V. (2009). Emerging multinationals from emerging markets. In R. Ramamurti \& J. V. Singh, (Eds.) Cambridge University Press. https://doi.org/10.1017/CBO9780511 576485

Ramli, M. F., \& Senin, A. A. (2015). Success factors to reduce orientation and resources-related barriers in university-industry R\&D collaboration particularly during development research stages. Procedia - Social and Behavioral Sciences, 172, 375-382. https://doi.org/10.1016/j.sbspro.2015.01.383

Ranga, M., Temel, S., Ar, I. M., Yesilay, R. B., \& Sukan, F. V. (2016). Building technology transfer capacity in Turkish universities: A critical analysis. European Journal of Education, 51(1), 90-106. https://doi.org/10.1111/ejed.12164

Rybnicek, R., \& Königsgruber, R. (2019). What makes industry-university collaboration succeed? A systematic review of the literature. Journal of Business Economics, 89(2), 221-250. https://doi. org/10.1007/s11573-018-0916-6

Santiago, F., De Fuentes, C., Dutrénit, G., \& Gras, N. (2017). What hinders innovation performance of services and manufacturing firms in Mexico? Economics of Innovation and New Technology, 26(3), 247-268. https://doi.org/10.1080/10438599.2016.1181297

Schiller, D., \& Lee, K. (2015). Are university-industry links meaningful for catch up? A comparative analysis of five Asian countries. In E. Albuquerque, W. Suzigan, G. Kruss, \& K. Lee (Eds.), Developing national systems of innovation: University-industry interactions in the global south. pp. 55-92. Edward Elgar Publishing. https://doi.org/10.4337/9781784711108.00010

Schiller, D., \& Liefner, I. (2007). Higher education funding reform and university-industry links in developing countries: The case of Thailand. Higher Education, 54(4), 543-556. https://doi.org/10. 1007/s10734-006-9011-y

Segarra-Blasco, A., \& Arauzo-Carod, J. M. (2008). Sources of innovation and industry-university interaction: Evidence from Spanish firms. Research Policy, 37(8), 1283-1295. https://doi.org/10. 1016/j.respol.2008.05.003

Şendoğdu, A. A., \& Diken, A. (2013). A research on the problems encountered in the collaboration between university and industry. Procedia - Social and Behavioral Sciences, 99, 966-975. https:// doi.org/10.1016/j.sbspro.2013.10.570

Sjolander, A., \& Martinussen, T. (2019). Instrumental variable estimation with the R package ivtools. Epidemiologic Methods. https://doi.org/10.1515/em-2018-0024

Skute, I., Zalewska-Kurek, K., Hatak, I., \& de Weerd-Nederhof, P. (2019). Mapping the field: A bibliometric analysis of the literature on university-industry collaborations. Journal of Technology Transfer, 44(3), 916-947. https://doi.org/10.1007/s10961-017-9637-1

Stojčić, N. (2021). Collaborative innovation in emerging innovation systems: Evidence from Central and Eastern Europe. The Journal of Technology Transfer, 46, 531-562. https://doi.org/10.1007/ s10961-020-09792-8

Tang, Y., Motohashi, K., Hu, X., \& Montoro-Sanchez, A. (2020). University-industry interaction and product innovation performance of Guangdong manufacturing firms: The roles of regional proximity and research quality of universities. Journal of Technology Transfer, 45(2), 578-618. https://doi.org/10. 1007/s10961-019-09715-2

Tartari, V., Salter, A., \& D'Este, P. (2012). Crossing the Rubicon: Exploring the factors that shape academics' perceptions of the barriers to working with industry. Cambridge Journal of Economics, 36(3), 655-677. https://doi.org/10.1093/cje/bes007

Tatoglu, E., \& Demirbag, M. (2008). Transition in the age of anxiety: The Turkish case. Journal of Management Development, 27(7), 653-659. https://doi.org/10.1108/02621710810883571

Teece, D. J., Pisano, G., \& Shuen, A. (1997). Dynamic capabilities and strategic management: Organizing for innovation and growth. Strategic Management Journal, 18(7), 509-533.

Temel, S., \& Glassman, B. (2013). Examining university-industry collaboration as a source of innovation in the emerging economy of Turkey. International Journal of Innovation Science, 5(1), 81-88. https:// doi.org/10.1260/1757-2223.5.1.81

Temel, S., Mention, A. L., \& Torkkeli, M. (2013). The impact of cooperation on firms' innovation propensity in emerging economies. Journal of Technology Management and Innovation, 8(1), 54-64. https:// doi.org/10.4067/S0718-27242013000100006 
Tsai, W. (2001). Knowledge transfer in intraorganizational networks: Effects of network position and absorptive capacity on business unit innovation and performance. Academy of Management Journal, 44(5), 996-1004. https://doi.org/10.2307/3069443

TUIK. (2019). Turkish Statistical Institute Research and Development Activities Survey 2018. http://www. turkstat.gov.tr/PreHaberBultenleri.do?id=30572. Accessed 29 January 2020

Uyarra, E. (2010). Conceptualizing the regional roles of universities, implications and contradictions. European Planning Studies, 18(8), 1227-1246. https://doi.org/10.1080/09654311003791275

Vansteelandt, S., Bowden, J., Babanezhad, M., \& Goetghebeur, E. (2011). On instrumental variables estimation of causal odds ratios. Statistical Science, 26(3), 403-422. https://doi.org/10.1214/11-STS360

Wooldridge, J. M. (2002). Chapter Fifteen: Instrumental variables estimation and two stage least squares. In Introductory economics. A modern approach. 2nd ed., pp. 461-500. Itps Thomson Learning.

Yalçıntaş, M., Kaya, C. Ç., \& Kaya, B. (2015). University-Industry Cooperation Interfaces in Turkey from Academicians' Perspective. Procedia - Social and Behavioral Sciences, 195, 62-71. https://doi.org/ 10.1016/j.sbspro.2015.06.330

Yaşar, M. M. (2019). Can Turkey escape from the middle-income trap? What has been done? What can be Done? Lessons from South Korea. Seoul Journal of Economics, 32(1), 63-82.

Yildirim, C. (2017). Turkey's outward foreign direct investment: Trends and patterns of mergers and acquisitions. Journal of Balkan and near Eastern Studies, 19(3), 276-293. https://doi.org/10.1080/19448 953.2017.1277084

Yu, G. J., \& Lee, J. (2017). When should a firm collaborate with research organizations for innovation performance? The moderating role of innovation orientation, size, and age. The Journal of Technology Transfer, 42(6), 1451-1465. https://doi.org/10.1007/s10961-016-9469-4

Yüksel, H., \& Cevher, E. (2014). Questioning the Collaboration between Universities and Industry : The Case of Turkey. International Journal of Humanities and Social Science, 4(7), 232-243.

Zaheer, A., \& Bell, G. G. (2005). Benefiting from network position: Firm capabilities, structural holes, and performance. Strategic Management Journal, 26(9), 809-825. https://doi.org/10.1002/smj.482

Zhang, Y., Li, H., Li, Y., \& Zhou, L.-A. (2010). FDI spillovers in an emerging market: The role of foreign firms' country origin diversity and domestic firms' absorptive capacity. Strategic Management Journal, 31(9), 969-989. https://doi.org/10.1002/smj.856

Publisher's Note Springer Nature remains neutral with regard to jurisdictional claims in published maps and institutional affiliations. 